\title{
HyPEP FY-07 Report: System Integration Model Development
}

C. H. Oh

E. S. Kim

S. R. Sherman

R. Vilim

April 2007

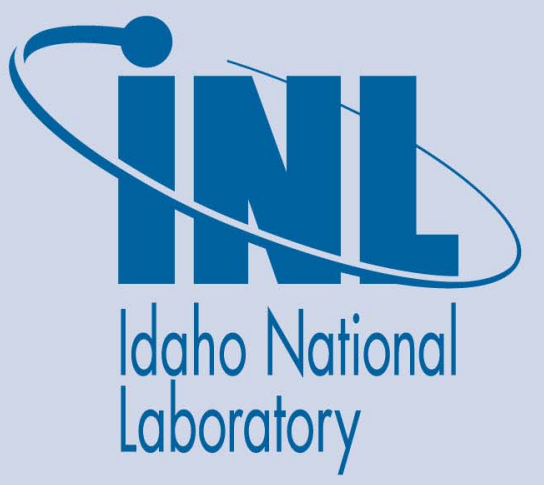

The INL is a U.S. Department of Energy National Laboratory operated by Battelle Energy Alliance 
INL/EXT-07-12470

\title{
HyPEP FY-07 Report: System Integration Model Development
}

\author{
C. H. $\mathrm{Oh}^{1}$ \\ E. S. Kim ${ }^{1}$ \\ S. R. Sherman ${ }^{1}$ \\ R. Vilim ${ }^{2}$ \\ ${ }^{1}$ INL
}

April 2007

Idaho National Laboratory

Idaho Falls, Idaho 83415

Prepared for the

U.S. Department of Energy

Office of Nuclear Energy

Under DOE Idaho Operations Office

Contract DE-AC07-05ID14517 


\begin{abstract}
The integrated system of a Very High Temperature Gas-Cooled Reactor (VHTR) and a High Temperature Steam Electrolysis (HTSE) process is one of systems being investigated by the U.S. Department of Energy and Idaho National Laboratory. This system will produce hydrogen by utilizing a highly efficient VHTR with an outlet temperature of $900{ }^{\circ} \mathrm{C}$ and supplying necessary energy and electricity to the HTSE process for electrolysis of high temperature steam.

This report includes a description of five configurations including an indirect parallel cycle, an indirect serial cycle, a direct serial cycle, a steam combined cycle, and a reheat cycle. HYSYS simulations were performed for each of these configurations coupled to a HTSE process. Final results are presented along with parametric studies and process optimization.
\end{abstract}




\section{CONTENTS}

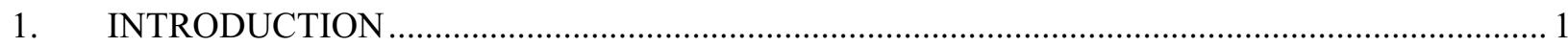

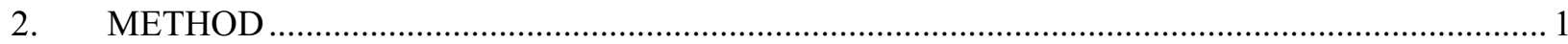

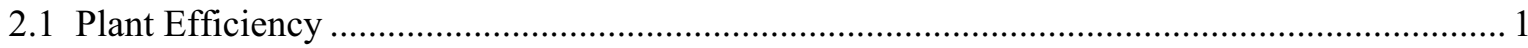

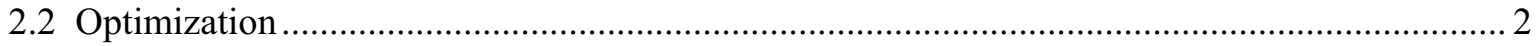

2.3 Electrolyzer Model for High Temperature Electrolysis (HTE) ............................................. 3

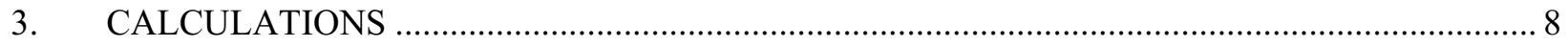

3.1 Efficiency Analysis of VHTR/HTSE Systems for Five Configurations .................................. 8

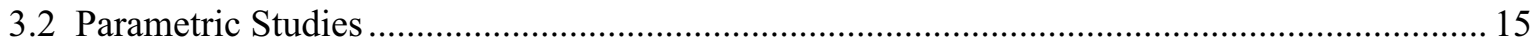

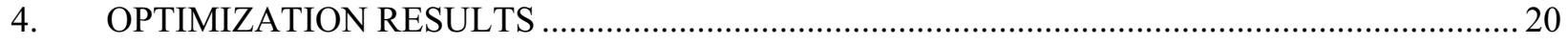

4.1 Configuration 1 - Indirect Parallel Cycle …......................................................................... 20

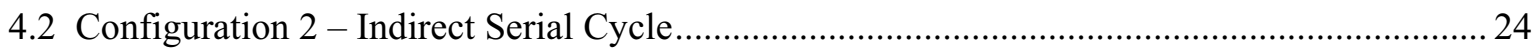

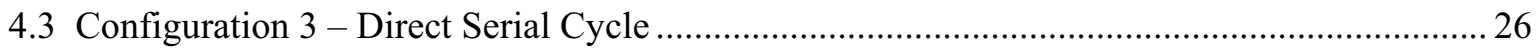

4.4 Configuration 4 - Steam Combined Cycle ……................................................................ 28

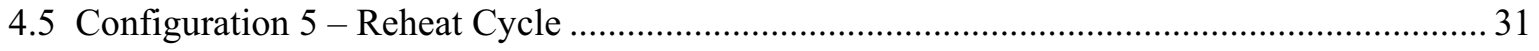

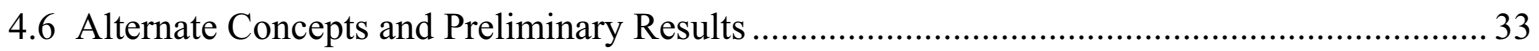

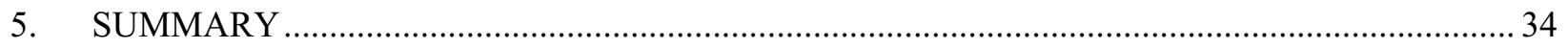

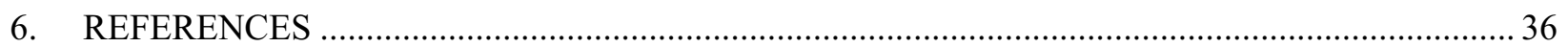




\title{
HyPEP FY-07 Report: Coupling Model Development
}

\author{
1. INTRODUCTION
}

The Next Generation Nuclear Plant (NGNP), a very High temperature Gas-Cooled Reactor (VHTR) concept, will provide the first demonstration of a closed Brayton cycle at a commercial scale of a few hundred megawatts electric and hydrogen production. The power conversion system (PCS) for the NGNP will take advantage of the significantly higher reactor outlet temperatures of the VHTR to provide higher efficiencies than can be achieved in the current generation of light water reactors. Besides demonstrating a system design that can be used directly for subsequent commercial deployment, the NGNP will demonstrate key technology elements that can be used in subsequent advanced power conversion systems for other Generation IV reactors. In anticipation of the design, development and procurement of an advanced power conversion system for the NGNP, the system integration of the NGNP and hydrogen plant was initiated to identify the important design and technology options that must be considered in evaluating the performance of the proposed NGNP. This study is part of DOE's Nuclear Hydrogen Initiative (NHI) Program, and is intended to provide DOE with key information to support the process of making research and procurement decisions for the NGNP system integration.

The HyPEP computer code is being developed to calculate and optimize electrical and hydrogen generation efficiencies in support of the NGNP [Oh et al. 2006a]. The calculations described in this report will be used to benchmark HyPEP.

\section{METHOD}

\subsection{Plant Efficiency}

The efficiency of each proposed configuration was estimated using HYSYS [Aspen Technology 2001], a process optimization code used in the chemical and oil industries.

The power conversion unit (PCU) cycle efficiency, $\eta_{P C U}$, used in this study is defined as [Oh et. al 2006]:

$\eta_{\mathrm{PCU}}=\frac{\text { Electric power output }}{\text { Reactor themal power }-\mathrm{H}_{2} \text { process power }}=\frac{\sum \mathrm{W}_{\mathrm{T}}-\sum \mathrm{W}_{\mathrm{C}}-\mathrm{W}_{\mathrm{S}}-\sum \mathrm{W}_{\mathrm{CIR}}}{\mathrm{Q}_{\mathrm{th}}-\mathrm{Q}_{\mathrm{H} 2}}$

where $\sum \mathrm{W}_{\mathrm{T}}$ is the total turbine workload, $\sum \mathrm{W}_{\mathrm{C}}$ is the total compressor workload, $\mathrm{W}_{\mathrm{S}}$ is the plant stationary load, $\sum \mathrm{W}_{\mathrm{CIR}}$ is the circulator workload in the primary, intermediate, and, if present, ternary loops and includes, for example, the recycle and make-up water pumps and the $\mathrm{H}_{2}$ and sweep water circulators, $\mathrm{Q}_{\mathrm{th}}$ is the reactor thermal power, and $\mathrm{Q}_{\mathrm{H} 2}$ is the thermal power supplied to the hydrogen generating plant. For the efficiency calculations, we report the overall cycle efficiency, which is defined as

$\eta_{\text {overall }}=\frac{\sum \mathrm{W}_{\mathrm{T}}-\sum \mathrm{W}_{\mathrm{C}}-\mathrm{W}_{\mathrm{S}}-\sum \mathrm{W}_{\mathrm{CIR}}-\sum \mathrm{Q}_{\mathrm{HTSE}}+\mathrm{Q}_{\mathrm{H} 2}^{\prime}}{\mathrm{Q}_{\text {th }}}$ 
where $\sum \mathrm{Q}_{\mathrm{HTSE}}$ is the electric power requirement for electrolysis and $\mathrm{Q}_{\mathrm{H} 2}^{\prime}$ is the hydrogen production mass flow rate times the specific energy content of the hydrogen.

\subsection{Optimization}

For this calculation, the process optimization was carried out using HYSYS process modeling software. HYSYS has an optimization tool that is built in to integrate the simulation model of the system. The optimization program searches for the maximum value of a given objective function subject to a number of imposed constraints. Figure 1 shows a two-dimensional design space with defined regions. The goal is to maximize $f(x 1, x 2, x 3, \ldots)$ where $x 1, x 2, x 3$ are independent variables such as mass flow, pressure, temperature, etc. For the optimization, the $\mathrm{x}$ variables are manipulated within a specified range of a lower and upper bound. The regions in Figure 1 are defined by a feasible design space within functional constraints and an infeasible design space outside of the constraint boundaries [Mckellar 1992]. Functional constraints are material and energy balances, for example, positive pressure drop in every stream in the direction of flow, positive power in turbine and compressor, temperature requirements at the inlet and outlet of the heat exchangers, etc. The function, $\mathrm{f}$, is the objective function which is defined as the overall plant efficiency above. Constant values of the objective function define contours on the design space. Figure 2 shows design space of 2-D design vector showing optimal design points. First, the initial calculation should be in the feasible design space and the search continues towards a direction in the design space until a maximum is reached. A new direction is found and the search continues in that direction as long as the objective function value increases. Once a maximum is reached, the search continues towards the optimal design point. However, if the optimal design point is outside of the feasible design space, the closest contour to the optimal solution that coincides with the constraint boundary can be the optimal solution within the constraints specified.

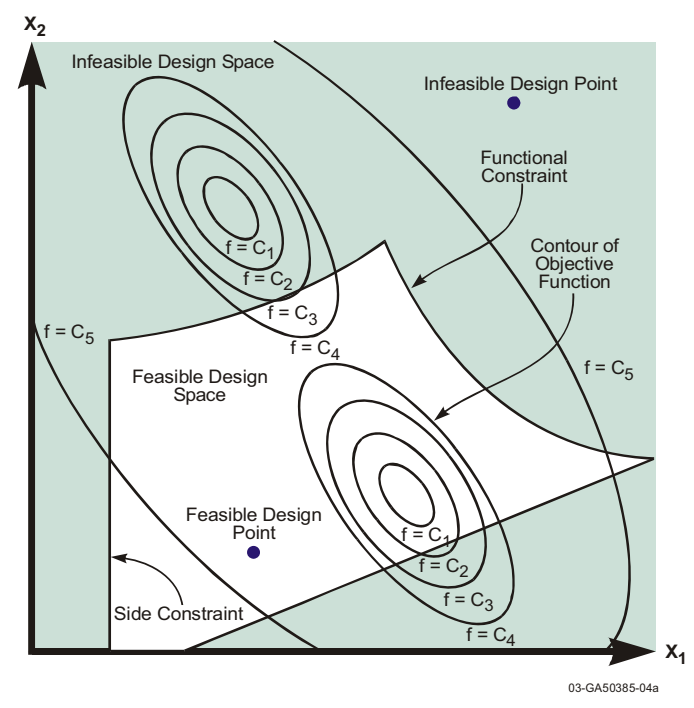

Figure 1. Design space with designed regions.

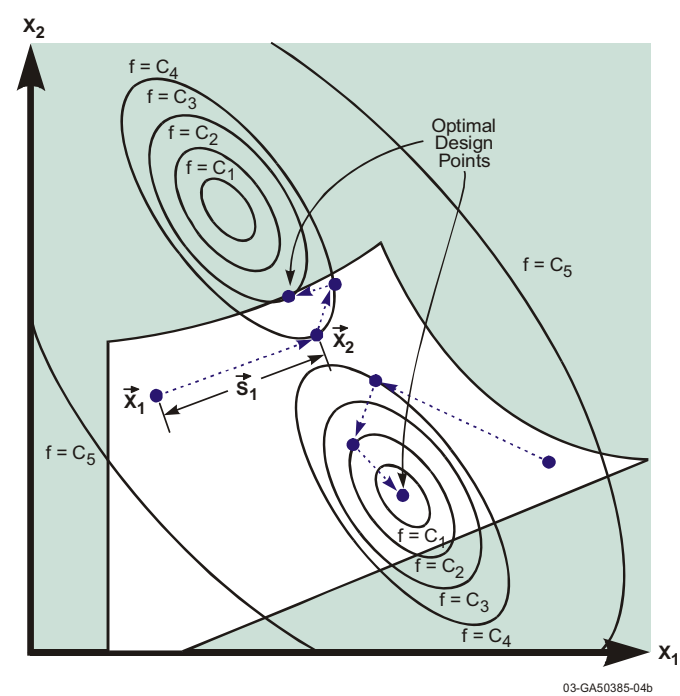

Figure 2. Potential optimal solutions. 


\subsection{Electrolyzer Model for High Temperature Electrolysis (HTE)}

In the electrolyzer model [Oh et al. 2006a], the oxygen stream produced at the anode is assumed to mix with a sweep gas stream that is introduced at the anode. The combined stream then exits the electrolyzer. The hydrogen stream produced at the cathode is assumed to mix with a feed stream that is introduced at the cathode. The feed stream is composed of water vapor to be electrolyzed, hydrogen gas for maintaining reducing environment, and possibly an inert gas, presently assumed to be nitrogen.

\section{A. Energy Equation}

An energy balance on the electrolyzer gives

$$
\sum_{i} \dot{n}_{P-i} H_{P-i}\left(T_{P}, P\right)=\sum_{i} \dot{n}_{R-i} H_{R-i}\left(T_{R}, P\right)+Q+W
$$

where

$$
\begin{array}{lll}
\dot{n} & = & \text { species mole flow rate } \\
\mathrm{H} & = & \text { enthalpy per mole } \\
Q & = & \text { rate of heat transfer to the electrolyzer, } \\
W & = & \text { rate of electrical work supplied to the electrolyzer } \\
T & = & \text { temperature }
\end{array}
$$

and where we have used subscripts $R$ for reactants and $P$ for products. Their mass flow rates are defined

$$
\begin{gathered}
m_{\mathrm{H}_{2} \mathrm{O}-\mathrm{O} \text {-cath }} h_{\mathrm{H}_{2} \mathrm{O}}\left(T_{o}, P\right)+m_{\mathrm{H}_{2}-\mathrm{O}-\text { cath }} h_{\mathrm{H}_{2}}\left(T_{o}, P\right)+m_{\mathrm{N}_{2}-\mathrm{O} \text {-cath }} h_{\mathrm{N}_{2}}\left(T_{o}, P\right) \\
m_{\mathrm{O}_{2} \text {-o-anode }} h_{\mathrm{O}_{2}}\left(T_{o}, P\right)+m_{\text {sweep-o-anode }} h_{\text {sweep }}\left(T_{o}, P\right)= \\
m_{\mathrm{H}_{2} \mathrm{O}-\text {-i-cath }} h_{\mathrm{H}_{2} \mathrm{O}}\left(T_{i}, P\right)+m_{\mathrm{H}_{2}-i \text {-cath }} h_{\mathrm{H}_{2}}\left(T_{i}, P\right)+m_{\mathrm{N}_{2}-i \text {-cath }} h_{\mathrm{N}_{2}}\left(T_{i}, P\right) \\
m_{\mathrm{O}_{2}-\mathrm{i} \text {-anode }} h_{\mathrm{O}_{2}}\left(T_{i}, P\right)+m_{\text {sweep-i-anode }} h_{\text {sweep }}\left(T_{i}, P\right)+Q+W
\end{gathered}
$$

where

$$
\begin{array}{lll}
m & = & \text { species mass flow rate }(\mathrm{kg} / \mathrm{s}), \\
h & = & \text { specific enthalpy }(\text { Joules } / \mathrm{kg}),
\end{array}
$$

and where subscripts $i$ and $o$ represent inlet and outlet, respectively.

B. Species Mole and Mass Flow rates

The species mole flow rates entering and leaving the electrolyzer are related to the current density through the relationships 


$$
\begin{aligned}
& \dot{n}_{\mathrm{H}_{2} \mathrm{O}-\mathrm{O}-\mathrm{cath}}=\dot{n}_{\mathrm{H}_{2} \mathrm{O}-\mathrm{i}-\mathrm{cath}}-\frac{i \mathrm{~A}}{2 \mathrm{~F}} \\
& \dot{n}_{\mathrm{H}_{2}-\mathrm{o}-\mathrm{cath}}=\dot{n}_{\mathrm{H}_{2}-i-\mathrm{cath}}+\frac{i \mathrm{~A}}{2 \mathrm{~F}} \\
& \dot{n}_{\mathrm{O}_{2}-\text { o-anode }}=\dot{n}_{\mathrm{O}_{2}-i \text {-anode }}+\frac{i \mathrm{~A}}{4 \mathrm{~F}} \\
& \dot{n}_{\text {sweep-o-anode }}=\dot{n}_{\text {sweep-i-anode }} \\
& \dot{n}_{N_{2}-o-c a t h}=\dot{n}_{N_{2}-i-c a t h}
\end{aligned}
$$

where

$$
\begin{array}{lll}
i & = & \text { current density }\left(\operatorname{amps} / \mathrm{m}^{2}\right), \\
A & = & \text { electrode surface area, }\left(\mathrm{m}^{2}\right) \text { and } \\
F & = & \text { Faradays constant. }
\end{array}
$$

The species mass flow rates and mole flow rates are related as follows: For an individual species

$$
\dot{m}_{k-o}=A_{k} \dot{n}_{k-o} \text { and } \dot{m}_{k-i}=A_{k} \dot{n}_{k-i}, \quad k=H_{2} O, H_{2}, O_{2} \text {, and } N_{2} \text {. }
$$

where $A_{k}$ is the atomic weight of species $k$ in $\mathrm{kg}$ per mole and subscript $o$ is the outlet and $i$ is the inlet.

\section{Cell Voltage and Electrical Work}

The voltage drop across the electrolyzer is the sum of the electrode Nernst potential and the resistance of the cell. In estimating the resistance, the activation and the concentration overpotentials are lumped in with the cell internal resistance. The cell voltage is then assumed given by

$$
\mathrm{V}_{\text {cell }}=\overline{\mathrm{V}}_{\text {Nernst }}+\mathrm{i} \cdot \mathrm{ASR}
$$

where

$$
\begin{array}{ll}
\overline{\mathrm{V}}_{\text {Nernst }}= & \text { is the Nernst potential, and } \\
\operatorname{ASR}= & \text { is the area-specific cell resistance }\left(\text { ohms }-\mathrm{m}^{2}\right)
\end{array}
$$

The electrical work done in the cell is

$$
W=V_{\text {cell }} \cdot i \cdot A
$$

The active species giving rise to the Nernst potential satisfy the chemical balance equation

$$
\mathrm{H}_{2} \mathrm{O}(\mathrm{g}) \rightarrow \mathrm{H}_{2}(\mathrm{~g})+\frac{1}{2} \mathrm{O}_{2}(g)
$$

The change in Gibbs free energy for this reaction carried out at temperature $\mathrm{T}$ and pressure $\mathrm{P}$ is 


$$
\Delta G(T, P)=\Delta G_{f}(T, P)+R T \ln \left[\frac{f_{H_{2}} f_{O_{2}}{ }^{\frac{1}{2}}}{f_{H_{2} O}}\right]
$$

where $f$ is the molar fraction of a species and $\Delta G_{f}(T, P)$ is the Gibbs free energy in forming the products at temperature $T$ and pressure $P$ minus the same for the reactants, that is,

$$
\Delta G_{f}(T, P)=G_{f-H_{2}}(T, P)+1 / 2 G_{f-O_{2}}(T, P)-G_{f-H_{2} O}(T, P) .
$$

where $\left.G_{f-i}(T, P)\right)$ is the Gibbs free energy on a per mole basis of forming species $i$ at conditions $T$ and $P$. In turn $\Delta G_{f}(T, P)$ is written in terms of $\Delta G_{f}^{0}(T)=\Delta G_{f}\left(T, P_{S T D}\right)$ where $P_{S T D}=0.101 \mathrm{MPa}$. Then setting the change in Gibbs free energy equal to the electrical work done the voltage developed by the cell is

$$
\mathrm{V}_{\text {Nernst }}=\frac{-1}{2 \mathrm{~F}}\left[\Delta G_{f}{ }^{0}(T)+R T \ln \left[\left(\frac{f_{\mathrm{H}_{2}} f_{\mathrm{O}_{2}}{ }^{\frac{1}{2}}}{f_{\mathrm{H}_{2} \mathrm{O}}}\right)\left(\frac{P}{P_{S T D}}\right)^{\frac{1}{2}}\right]\right]
$$

where $P_{S T D}=0.101 \mathrm{MPa}$ and $P$ is the cell pressure. Then the average value of $\mathrm{V}_{\text {Nernst }}$ was calculated suing the following equation.

$$
\begin{aligned}
\bar{V}_{\text {Nernst }}=\frac{1}{2 F\left(T_{P}-T_{R}\right)\left(y_{0, \mathrm{O} 2, \mathrm{~A}}-y_{\mathrm{i}, \mathrm{O} 2, \mathrm{~A}}\right)\left(\mathrm{y}_{\mathrm{o}, \mathrm{H} 2, \mathrm{C}}-\mathrm{y}_{\mathrm{i}, \mathrm{H} 2, \mathrm{C}}\right)} \times \\
\int_{\mathrm{T}_{\mathrm{R}}}^{\mathrm{T}_{\mathrm{P}}} \int_{\mathrm{y}_{\mathrm{i}, \mathrm{O} 2, \mathrm{~A}} \mathrm{y}_{\mathrm{i}, \mathrm{H} 2, \mathrm{C}}}^{\mathrm{y}_{\mathrm{O}, \mathrm{O} 2, \mathrm{~A}} \mathrm{y}_{\mathrm{o}, \mathrm{H} 2, \mathrm{C}}} \Delta \mathrm{G}(\mathrm{T})-\mathrm{RT} \ln \left(\frac{1-\mathrm{y}_{\mathrm{H} 2}-\mathrm{y}_{\mathrm{N} 2}}{\mathrm{y}_{\mathrm{H} 2} \mathrm{y}_{\mathrm{O} 2}{ }^{1 / 2}}\right) \mathrm{dy}_{\mathrm{H} 2} \mathrm{dy}_{\mathrm{O} 2} \mathrm{dT}
\end{aligned}
$$

The mole fractions at any point in the electrolyzer are related to the molar mass flow rates at that point through

$$
\begin{array}{ll}
f_{\mathrm{H}_{2} \mathrm{O}-\text { cath }}=\frac{\dot{n}_{\mathrm{H}_{2} \mathrm{O}}}{\dot{n}_{\mathrm{H}_{2} \mathrm{O}}+\dot{n}_{\mathrm{H}_{2}}+\dot{n}_{\mathrm{N}_{2}}} & f_{\mathrm{H}_{2} \text {-cath }}=\frac{\dot{n}_{\mathrm{H}_{2}}}{\dot{n}_{\mathrm{H}_{2} \mathrm{O}}+\dot{n}_{\mathrm{H}_{2}}+\dot{n}_{\mathrm{N}_{2}}} \\
f_{\mathrm{O}_{2} \text {-anode }}=\frac{\dot{n}_{\mathrm{O}_{2}}}{\dot{n}_{\text {sweep }}+\dot{n}_{\mathrm{O}_{2}}} & f_{\text {sweep-anode }}=\frac{\dot{n}_{\text {sweep }}}{\dot{n}_{\text {sweep }}+\dot{n}_{\mathrm{O}_{2}}} .
\end{array}
$$

The current density and active cell area are then specified, yielding the total operating current. Care must be taken to insure that the specified inlet gas flow rates and total cell current are compatible. The minimum required inlet steam molar flow rate is the same as the steam consumption rate, given by:

$$
\dot{N}_{i, H 2 O, \min }=\Delta \dot{N}_{H 2 O}=\frac{I}{2 F} N_{c e l l s}=\frac{i A_{c e l l}}{2 F} N_{c e l l s}=\Delta \dot{N}_{H 2}
$$


which is of course also equal to the hydrogen production rate.

Once the total and per-cell hydrogen production rates are known, the outlet flow rates of hydrogen and steam on the cathode side and oxygen on the anode side can be determined. The flow rates of any inert gases, the anode-side sweep gas, and any excess steam or hydrogen are the same at the inlet and the outlet. Once all these flow rates are known, the summations in Equation (3) can be evaluated. The product summation must be evaluated initially at a guessed value of the product temperature, $T_{P}$.

Matlab (Mathworks 2006) was used to calculate Equations (3) through (15). Figures 3 through 5 illustrate the calculated results. Figure 3 contains two curves. One curve shows the required electrical work with current density at a fixed total current. The other curve shows the required number of cells to obtain the current density. As shown in this figure, electrical work increases with current density because higher current density results in higher operating voltage as shown in Equation (8) and Figure 4.

However, the number of cells is reduced by the increase of current density. So, economically, the increase of current density increases the operating cost, but reduces the capital cost. Therefore, the operating condition of the current density should be carefully determined under various economic considerations. To obtain the optimal operating current density, further optimization analysis is recommended.

Figure 5 shows the variation of product temperature with total electric current. Basically, the water splitting process is an endothermic reaction. Therefore, without additional heat, the product temperature is reduced. In Figure 5, we can see the temperature reaches a minimum between 5 and 15 amperes. At the higher current density, we can see the temperature gradually turns upward. It is due to the ohmic heating by the cell internal resistance. The heating rate also increases with the current density causing the product gas temperature rise.

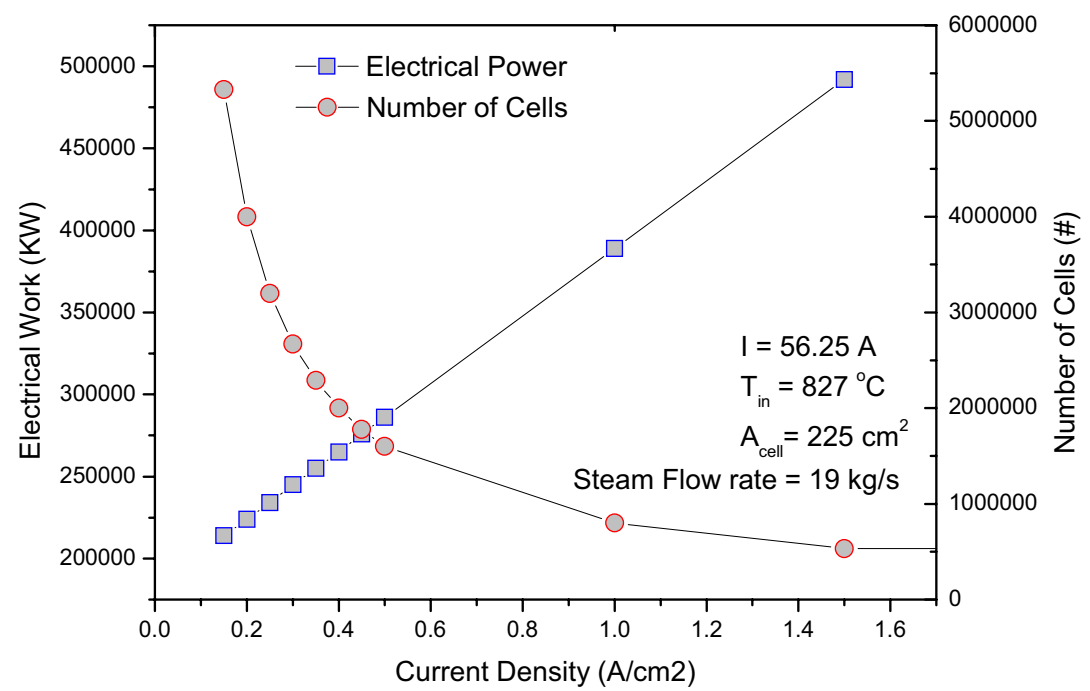

Figure 3. Required electrical work and number of cells with current density at the constant current. 


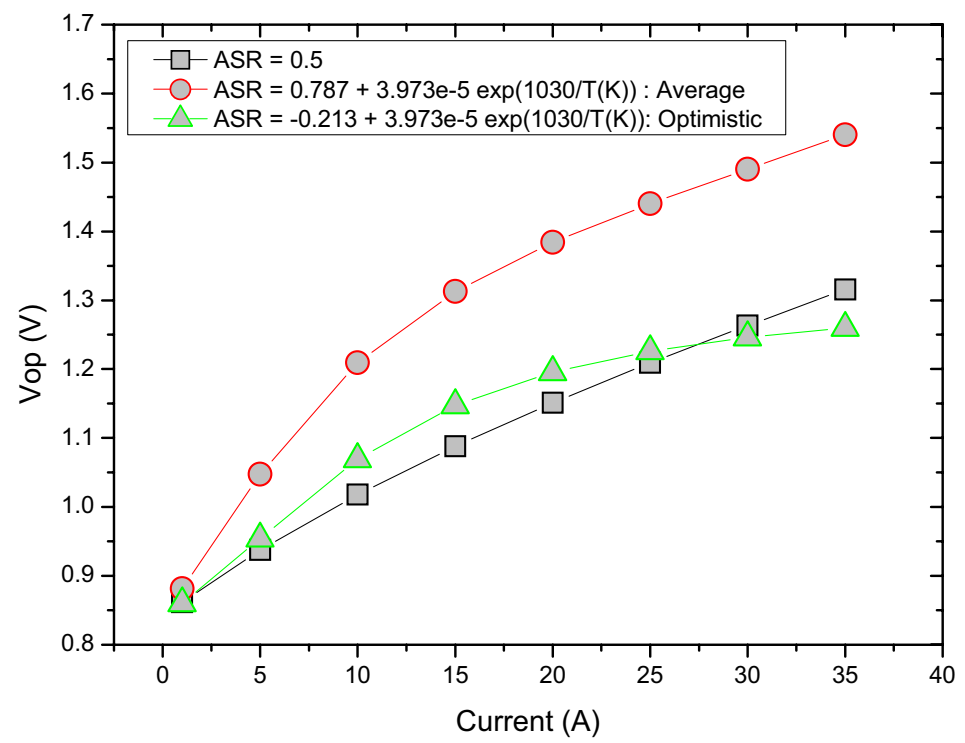

Figure 4. Variation of cell operating voltage with current for different stack area-specific resistance (ASR).

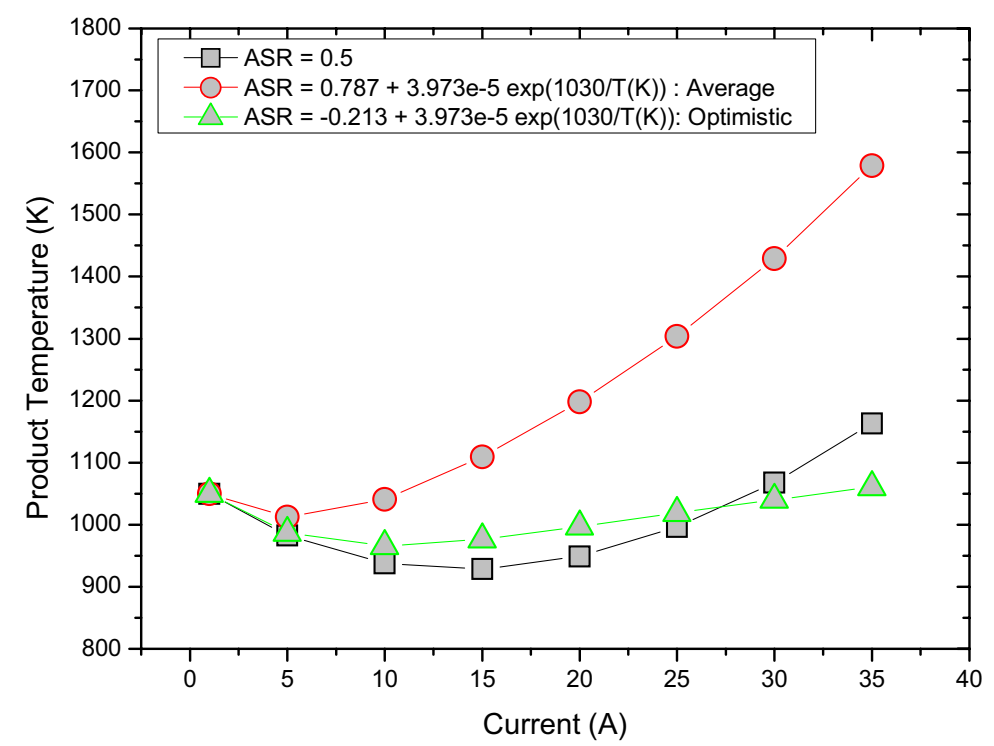

Figure 5. Variation of product temperature with current for different ASR. 


\section{CALCULATIONS}

\subsection{Efficiency Analysis of VHTR/HTSE Systems for Five Configurations}

The current work is focused on the integration of the VHTR and the HTSE. In this system, the heat generated in the reactor core is transferred to the HTSE system through various heat exchangers that increase the steam temperature to more than $800^{\circ} \mathrm{C}$. The electrolyzer is made of Solid Oxide Fuel Cells that convert the heated steam into hydrogen and oxygen molecules. Approximately 10 percent of the total energy transferred is supplied by heat and the rest is supplied by electricity, which is generated in the PCU integrated in the VHTR system. The PCU is based on the widely-used closed-loop gas Brayton cycle, which shows high efficiency especially at higher temperatures. The reactor core and PCU are integrated in two different configurations; the direct cycle and the indirect cycle. In the direct cycle, the PCU is located in the primary system in series with the reactor core. In the indirect cycle, the primary system and PCU are separated by a heat exchanger resulting in a more complicated configuration and reduced efficiency. However, separating the reactor core from the PCU results in easier maintenance and should reduce the strong dynamic coupling between the core and PCU, which may improve safety. The Independent Technology Review Group [2004] has recommended an indirect cycle and the maximum VHTR outlet temperature of $900{ }^{\circ} \mathrm{C}$, based in part on material problems associated with higher temperatures.

In the current study, the efficiency of VHTR/HTSE system has been estimated using HYSYS, a commercial process flowsheet analysis code that has been used in chemical and petroleum industry. The HYSYS code supports models for many basic system components and has a process optimization capability. Typical HYSYS components used in this study are a reactor, pump, compressor, heat exchanger, turbine, cooler, and vessel. VHTR system modules of various configurations are developed with these basic components.

Since HYSYS does not have a model for electro-chemical processes, an electrolyzer model was developed. This model was then integrated into the HYSYS model for the balance of the HTSE process. A HYSYS model for the VHTR system was then combined with the HTSE system to obtain the combined VHTR/HTSE plant simulation. The details of the models are described below.

\section{$\underline{\text { System Configurations for Reference Designs }}$}

In this study, the following five different configurations of the integrated system are evaluated in terms of the overall hydrogen production efficiency.

(1) Configuration 1 - Indirect Parallel Cycle (Figures 6 and 7)

(2) Configuration 2 - Indirect Serial Cycle (Figure 8)

(3) Configuration 3 - Direct Serial Cycle (Figure 9)

(4) Configuration 4 - Steam Combined Cycle (Figure 10)

(5) Configuration 5 - Reheat Cycle (Figure 11)

Figure 6 illustrates the indirect parallel system. The flow in the secondary coolant system is divided, with most of the flow going towards the PCU and the remainder going through a secondary heat exchanger (SHX) that directs heat towards the HTSE plant. The flow through the hot side of the SHX is then mixed with the flow from the PCU to feed the cold side of the intermediate heat exchanger (IHX). However, some of the flow is diverted away from the PCU, which acts to decrease the efficiency of the cycle. 
There are three coolant loops. The primary coolant system contains the nuclear reactor, the hot side of the IHX, and a compressor. The secondary coolant system contains the cold side of the IHX, the hot side of the SHX, the PCU, and connecting piping, which is assumed to be short. The intermediate heat transport loop connects the secondary coolant system to the HTSE plant through several process heat exchangers (PHXs).

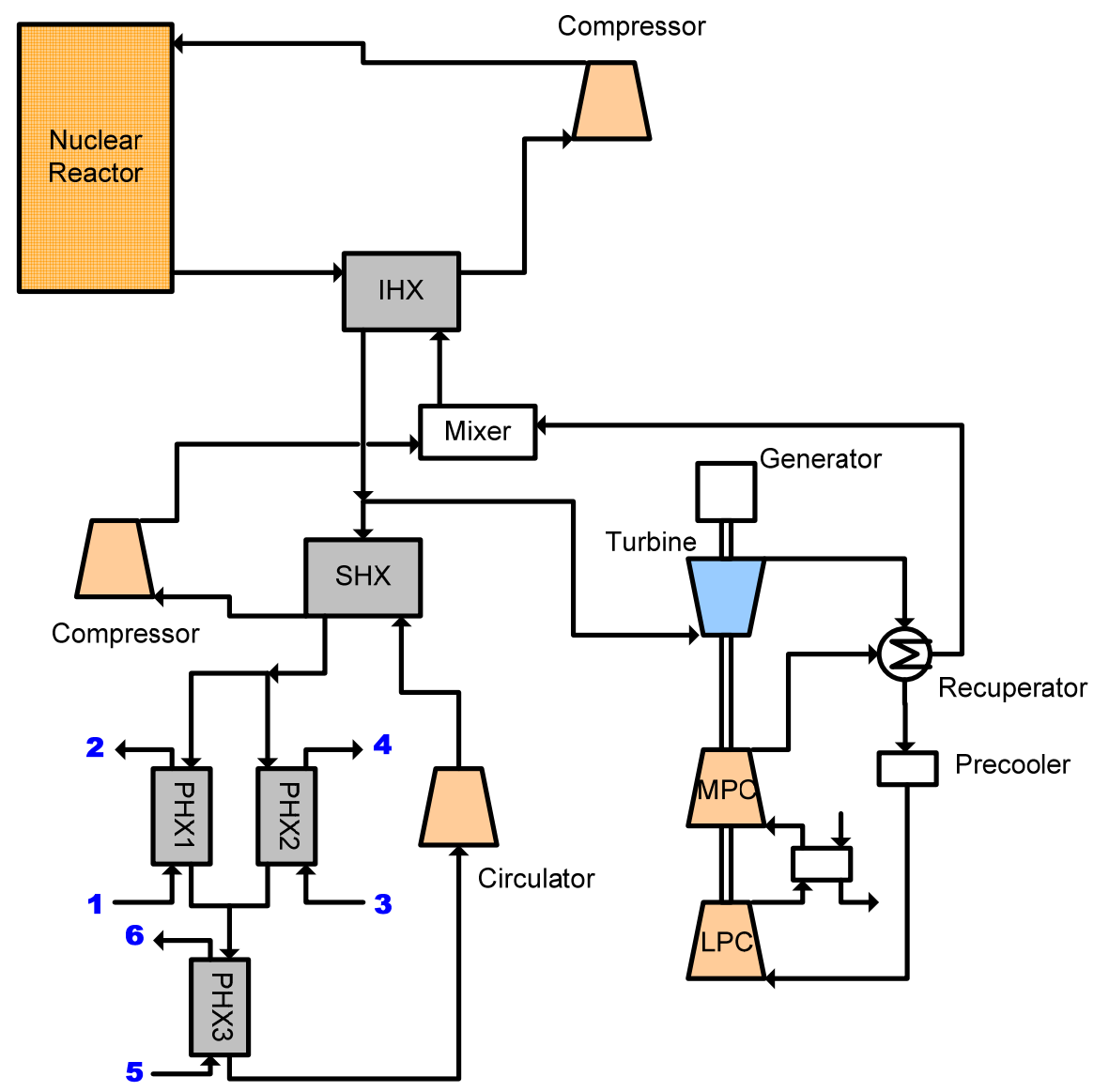

Figure 6. Configuation 1 - indirect parallel cycle.

For electrolysis, the steam is heated up to higher than $800^{\circ} \mathrm{C}$ by the heat from SHX. The heated steam is converted into hydrogen and oxygen in the electrolyzer and discharged through the fuel and oxidizer outlet, respectively as shown in Figure 7. The heat of the discharged gases is recovered through three recuperators. Finally, the product gas in the fuel side contains hydrogen and steam, and the oxidizer outlet gas contains oxygen and steam. As shown in Figure 7, the discharged fuel steam is recycled to the inlet fuel stream, and the hydrogen gas is separated and collected in the separator. In the oxidizer outlet stream heat is first recuperated and then the stream is run through an expander to recover work. The oxygen and water components of the stream are then separated. 


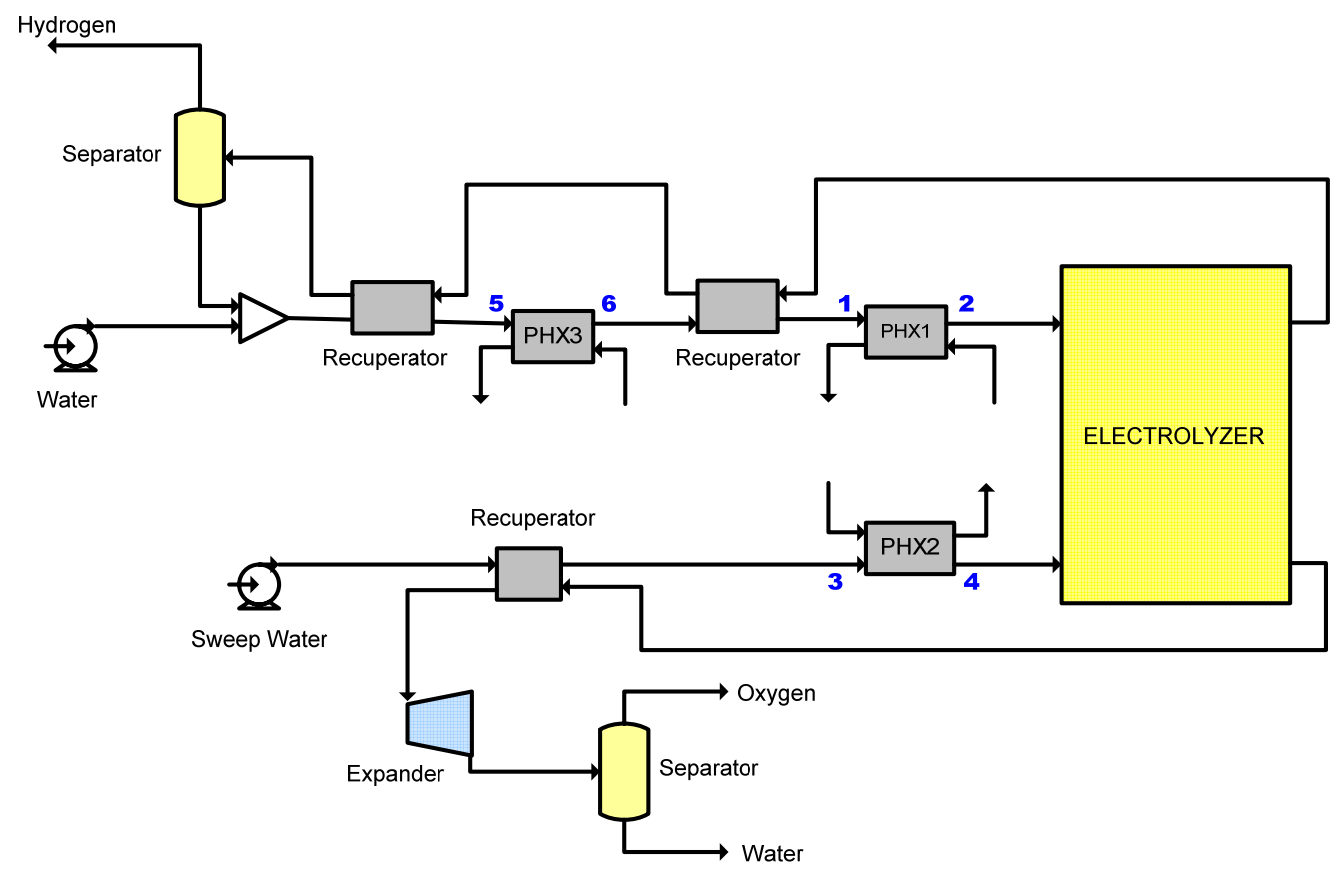

Figure 7. HTSE system.

Figure 8 illustrates the indirect serial configuration. In this configuration, SHX is located upstream of the IHX that is linked to the PCU. Therefore, the heat from the VHTR is firstly transferred to the HTSE system, and then it is transferred to the PCU. This configuration is able to supply higher temperature to the HTSE system, but decreases the PCU maximum temperature, resulting in a decreased PCU efficiency. However, in this configuration, the system is more controllable due to its less connectivity. The reduction in the number of circulators can reduce the cost and increase the overall efficiency. The same HTSE system configuration as shown in Figure 7 is used here in terms of coupling the VHTR and the HTSE. 


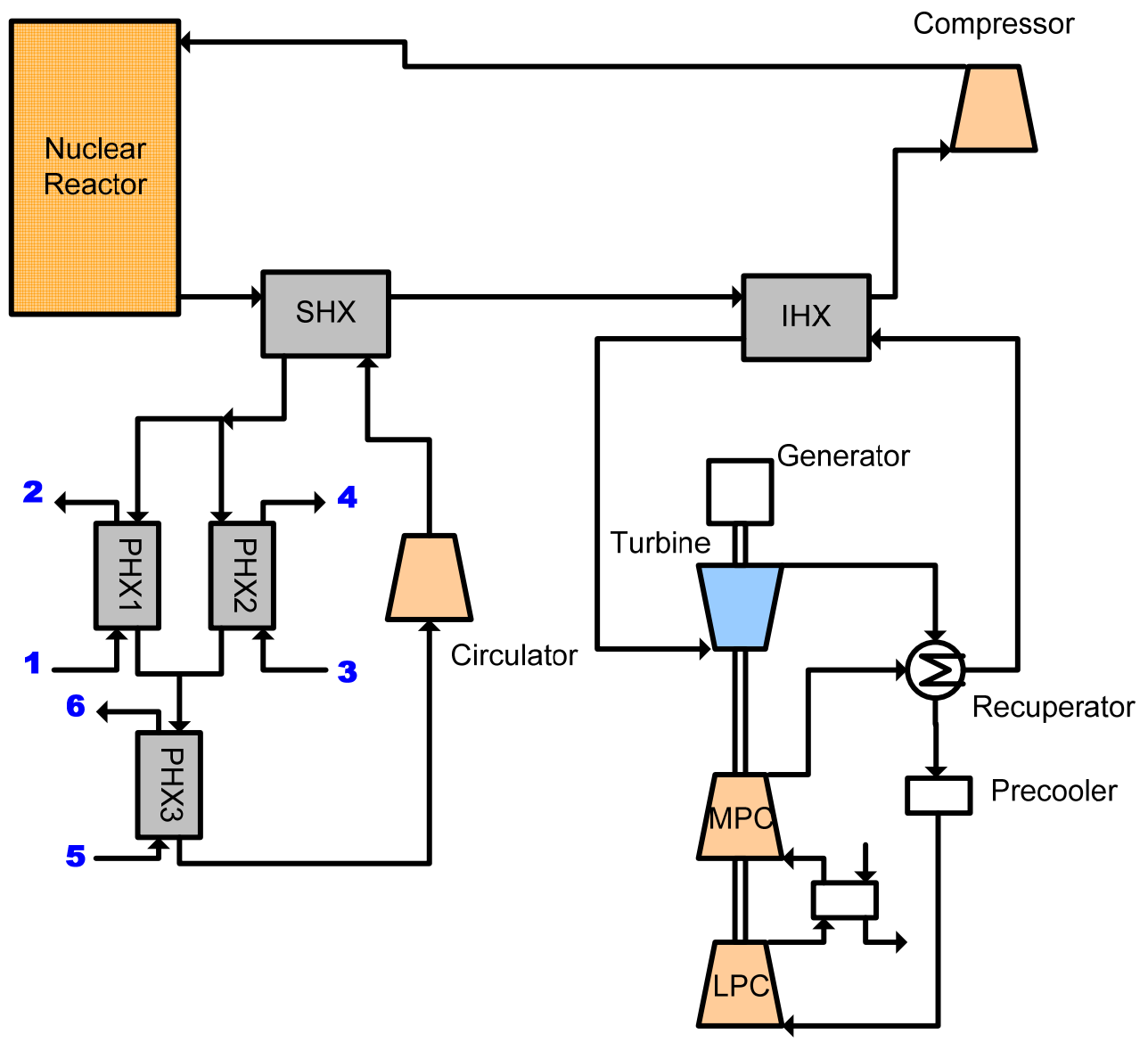

Figure 8. Configuration 2 - indirect serial cycle.

Figure 9 depicts Configuration 3, which is a direct serial cycle. The outlet stream of the VHTR flows through the SHX and then flows to the high pressure turbine. The system integration is very similar to the previous configurations in terms of utilizing heat through PHX1, PHX2, and PHX 3 that are linked to the HTSE via streams 1 to 6 as shown in Figure 9.

Even though the indirect configuration was recommended by the Independent Technology Review Group [2004], the direct cycle was also considered in this study due to its simplicity, high efficiency, and economics. In this configuration, the primary side is integrated with the PCU, which leads to the elimination of the large IHX between the core and the PCU and the circulator in the primary side. As a result, it increases the efficiency and will reduce the capital cost. However, on the other hand, there will be some possibilities of safety and maintenance problems. In this configuration, the HTSE system is connected to VHTR through the SHX. The HTSE system is the same as the previous configurations. 


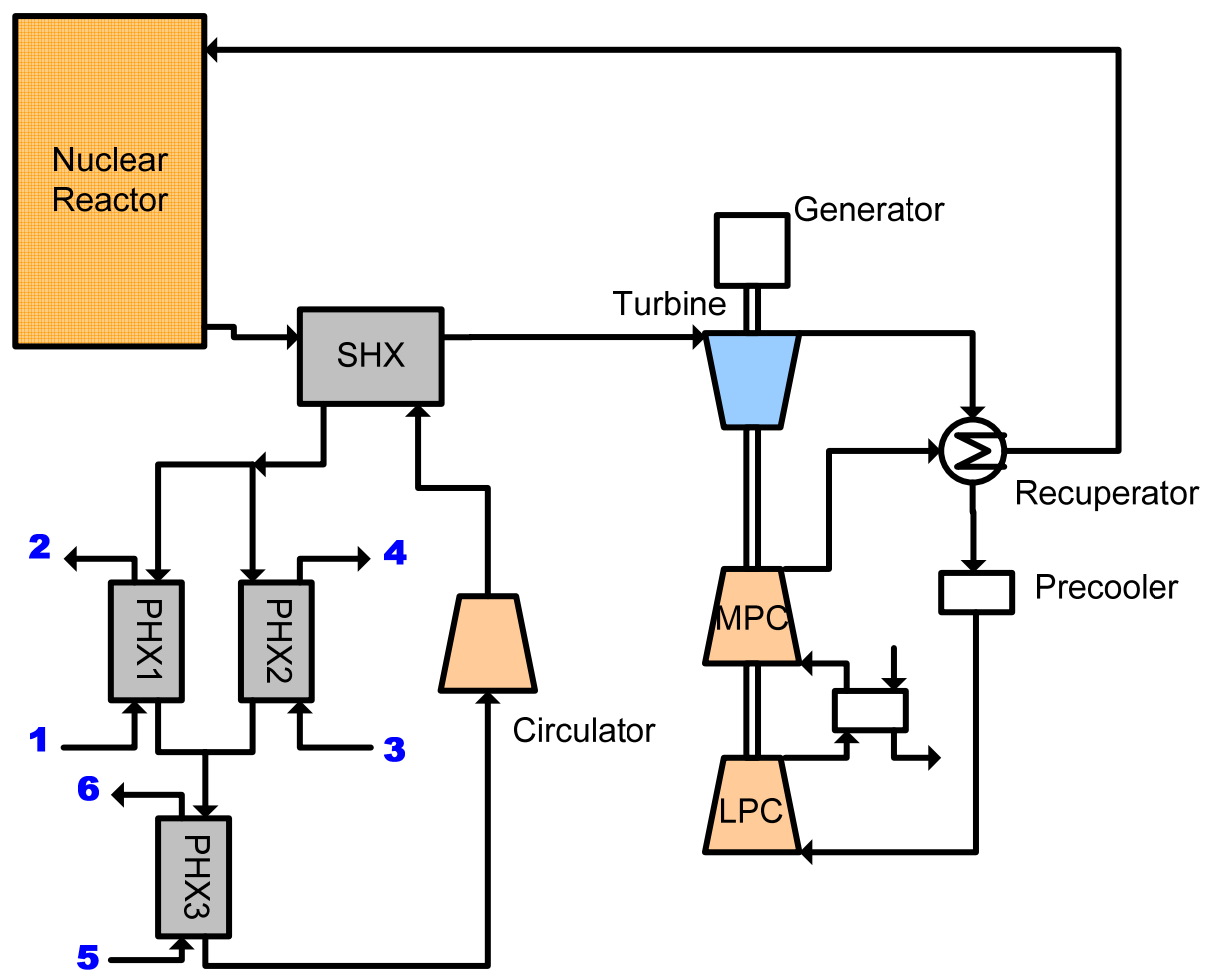

Figure 9. Configuration 3 - direct serial cycle.

Figure 10 illustrates the steam combined system. This configuration is basically the same as the Configuration 1 (indirect parallel cycle), but the recuperator is replaced with the steam turbine cycle. This configuration is commonly used to maximize the gas turbine efficiency and heat recovery in combined cycle power plants. The advantage of this configuration is due to the reduced pumping power for water in the Rankine cycle compared with that of the high pressure gas media. 


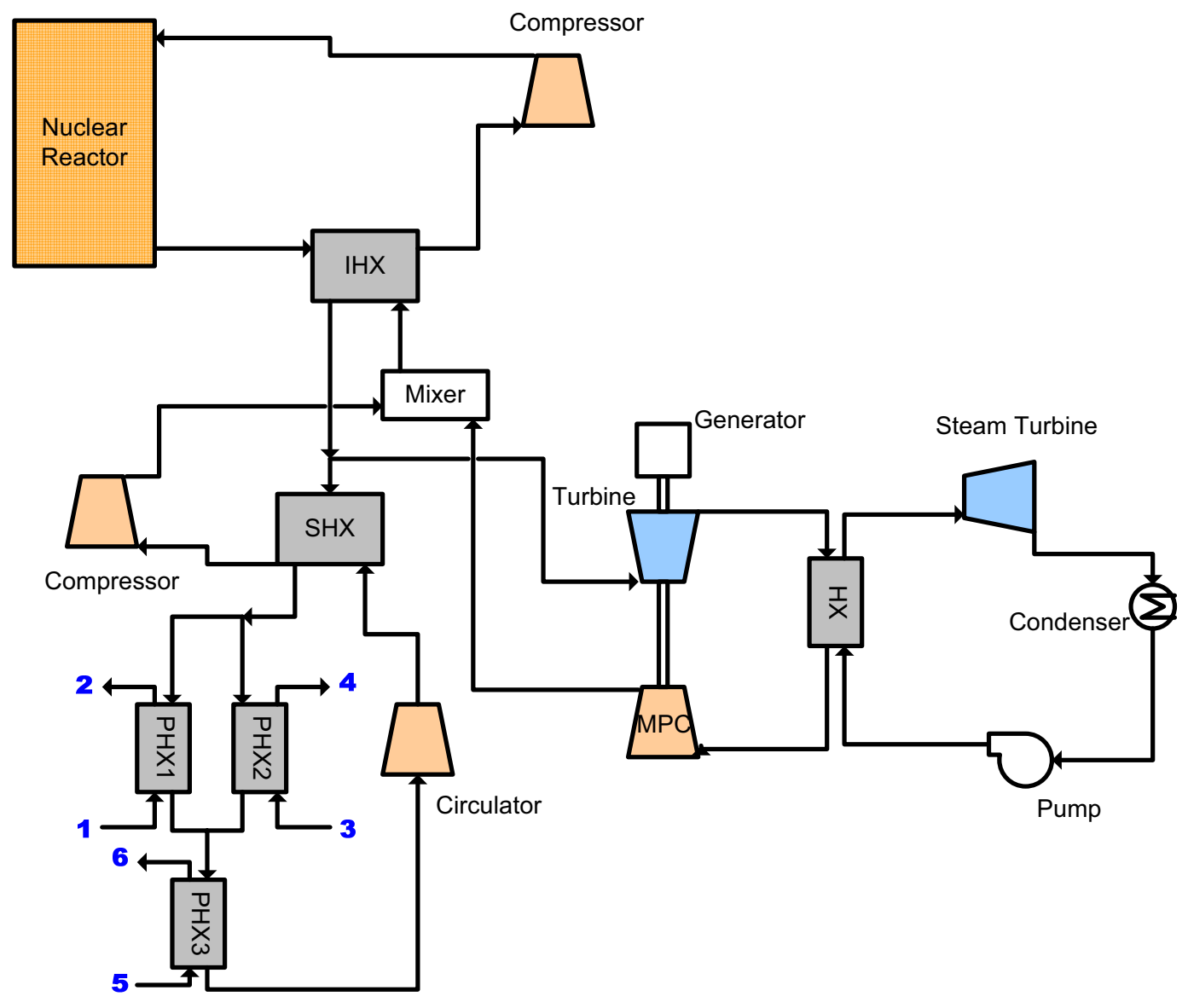

Figure 10. Configuration 4 - steam combined cycle.

Figure 11 illustrates the reheat cycle. This configuration is included to determine how much the reheat option can enhance the cycle efficiency and to investigate technical issues associated with the reheat option. For these calculations, a cycle with multiple preheaters and coolers was used. Molten salt is the coolant fluid on the primary side and helium in the Brayton cycle. Theoretically a combination of reheat and intercooling increases the cycle efficiency in a closed cycle, but the full implications have not been explored. Multiple-reheat is technically viable for closed gas cycles [Oh et al. 2006b]. For gas-cooled reactors, a multiple reheat option may not be practical due to higher-pressure loss associated with gases, i.e., helium, supercritical $\mathrm{CO}_{2}$, and nitrogen. However, molten salt coolants can transport heat with low pumping power, which becomes very attractive without any consideration of material problems associated with molten coolants at high temperatures.

In this configuration, the discharged gas from a turbine is reheated and re-introduced to other turbines. This process usually leads to higher efficiency and power density. However, it requires more system components such as extra turbines and compressors resulting in higher capital cost. The size of turbines and compressors in this configuration will be smaller than those configurations with one turbine and one/two compressors because the total turbine and compressor work will be the same regardless of the number of turbomachines. The HTSE system is connected through the SHX and the configuration is the same as the previous systems. 

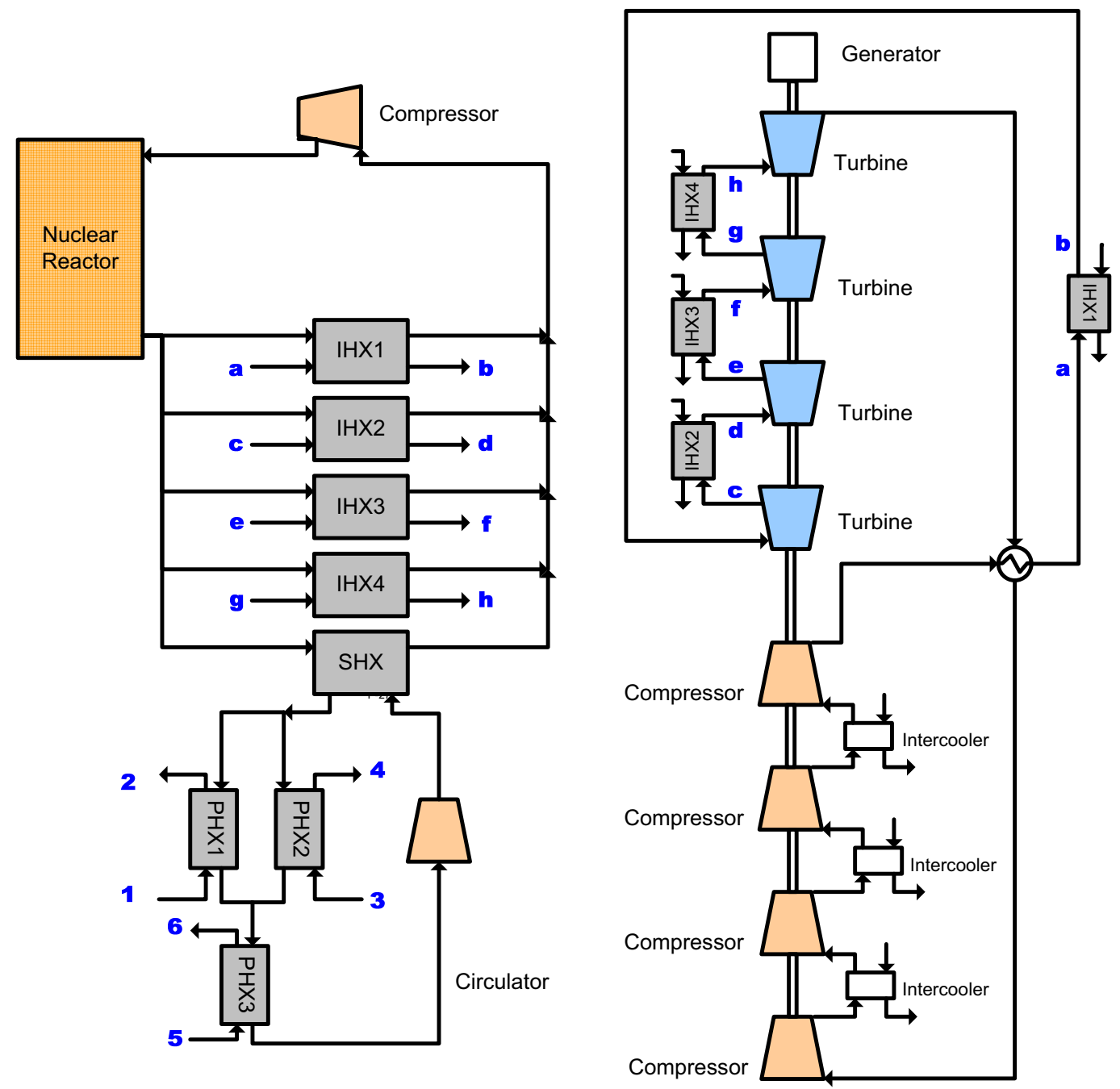

Figure 11. Configuration 5 - reheat cycle.

\section{Working Fluids}

In this work, the effect on efficiency of the following three coolants is estimated:

(1) Helium

(2) Supercritical carbon dioxide $\left(\mathrm{S}-\mathrm{CO}_{2}\right)$

(3) Flinak (LiF-NaF-KF)

Helium is the basic working fluid used in most VHTR designs. It can be used for all parts of the system; in the primary side for core cooling, the secondary side for Brayton cycle, and the ternary side for transferring heat to the HTSE. S- $\mathrm{CO}_{2}$ can be used for the secondary and ternary sides, but not for the primary side because of its chemical reaction with the graphite materials installed in the primary core. Flinak is one kind of molten salt coolant and is very nearly incompressible. It can be used for primary core cooling and ternary heat exchange loop. However, it can not be used in the PCU because the 
turbomachinery require a compressible substance. In this study, we organized all the possible combinations of working fluids, and performed efficiency optimization and analysis. Table 1 summarizes the physical properties for those coolant materials.

Table 1. Physical properties for working fluids (at $900^{\circ} \mathrm{C}, 7 \mathrm{MPa}$ ).

\begin{tabular}{|l|c|c|c|}
\hline & Helium & S-CO & $\begin{array}{c}\text { Flinak (LiF-NaF- } \\
\text { KF) }\end{array}$ \\
\hline Formula Wt (g/mol) & 4.003 & 44.01 & 41.2 \\
\hline Melting Point $\left({ }^{\circ} \mathbf{C}\right)$ & - & - & 454 \\
\hline Density (kg/m3) & 2.859 & 1.06 & 1528 \\
\hline $\begin{array}{l}\text { Heat Capacity } \\
\left(\mathbf{k J} / \mathbf{k g m o l}-{ }^{\circ} \mathbf{C}\right)\end{array}$ & 20.78 & $5.161 \mathrm{e}-5$ & 88.35 \\
\hline Viscosity (Pa s) & $2.703 \mathrm{e}-3$ & 0.07885 & $1.963 \mathrm{e}-4$ \\
\hline $\begin{array}{l}\text { Thermal } \\
\text { Conductivity } \\
\left(\mathbf{W} / \mathbf{m}^{\circ}{ }^{\circ} \mathbf{C}\right)\end{array}$ & 0.2517 & Gas & 0.8612 \\
\hline Phase & Gas & & Liquid \\
\hline
\end{tabular}

\subsection{Parametric Studies}

In this section, the effects on the plant efficiency were estimated for various operating parameters. These parameters included reactor inlet temperature and turbine and compressor efficiencies. Note that the parametric studies on reactor inlet temperature were performed with the reactor outlet temperature fixed at $900{ }^{\circ} \mathrm{C}$, which is assumed dictated by HTSE system requirements. The Configuration 1 system with $\mathrm{He}-\mathrm{He}-\mathrm{He}$ working fluids combination was selected as the reference case for analysis (refer to Table 2).

Figure 12 shows the effect of compressor efficiency and core inlet temperature on the overall system efficiency. As shown in this figure, the system efficiency increases with the compressor efficiency. The maximum efficiency ranges around the core inlet temperature of $600 \sim 700{ }^{\circ} \mathrm{C}$. The reason for the efficiency increase with compressor efficiency is obvious because high compressor efficiency reduces irreversibility of the system. In our calculation, one percent increase of compressor efficiency results in about $0.3 \sim 0.6$ percent increase of overall efficiency. Thus, improving the compressor efficiency is a very useful way to get a more efficient system. Of course, this also means that a decrease of the compressor efficiency during operation can cause the overall efficiency to decrease.

The effect of core inlet temperature is quite complicated. Core inlet temperature is closely related to PCU flow rate, and also directly to the flow rate in the primary side. As the core inlet temperature is raised, the PCU flow rate can also be increased, resulting in PCU efficiency increase. However, the increase of core inlet temperature requires higher flow rate in the primary side (since reactor power and outlet temperature are maintained constant), requiring higher circulation power. As shown in Figure 12, the overall efficiency increases with core inlet temperature below $500{ }^{\circ} \mathrm{C}$ from the increase of PCU flow rate, but above $600^{\circ} \mathrm{C}$, the efficiency is reduced due to the increase of circulation power. Essentially, there is a break point where the decrease in efficiency from increased compressor losses is opposite and equal to the efficiency gain resulting from a higher average core temperature. 


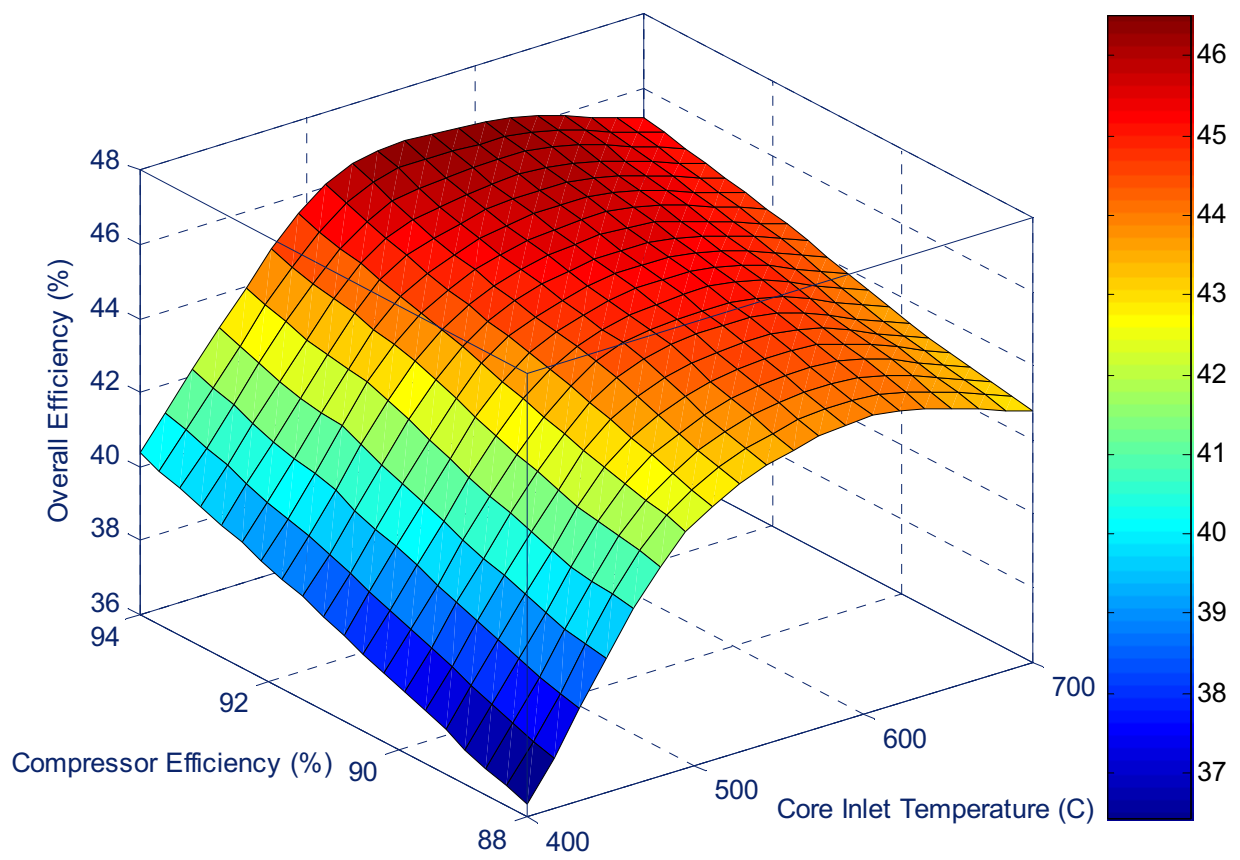

Figure 12. Effect of core inlet temperature and compressor efficiency on overall plant efficiency (He-He$\mathrm{He})$.

Figure 13 shows the effects of turbine efficiency and core inlet temperature on overall efficiency. The optimal temperature occurred around $650{ }^{\circ} \mathrm{C}$. As expected, the overall efficiency was increased with turbine efficiency. One percent increase of turbine efficiency caused $0.5 \sim 0.9 \%$ increase of overall efficiency. However, the rate of increase decreased as the operating temperature approached the optimal temperature. In this study, the efficiency of turbine seems to affect the overall efficiency a little more than the efficiency of one compressor. 


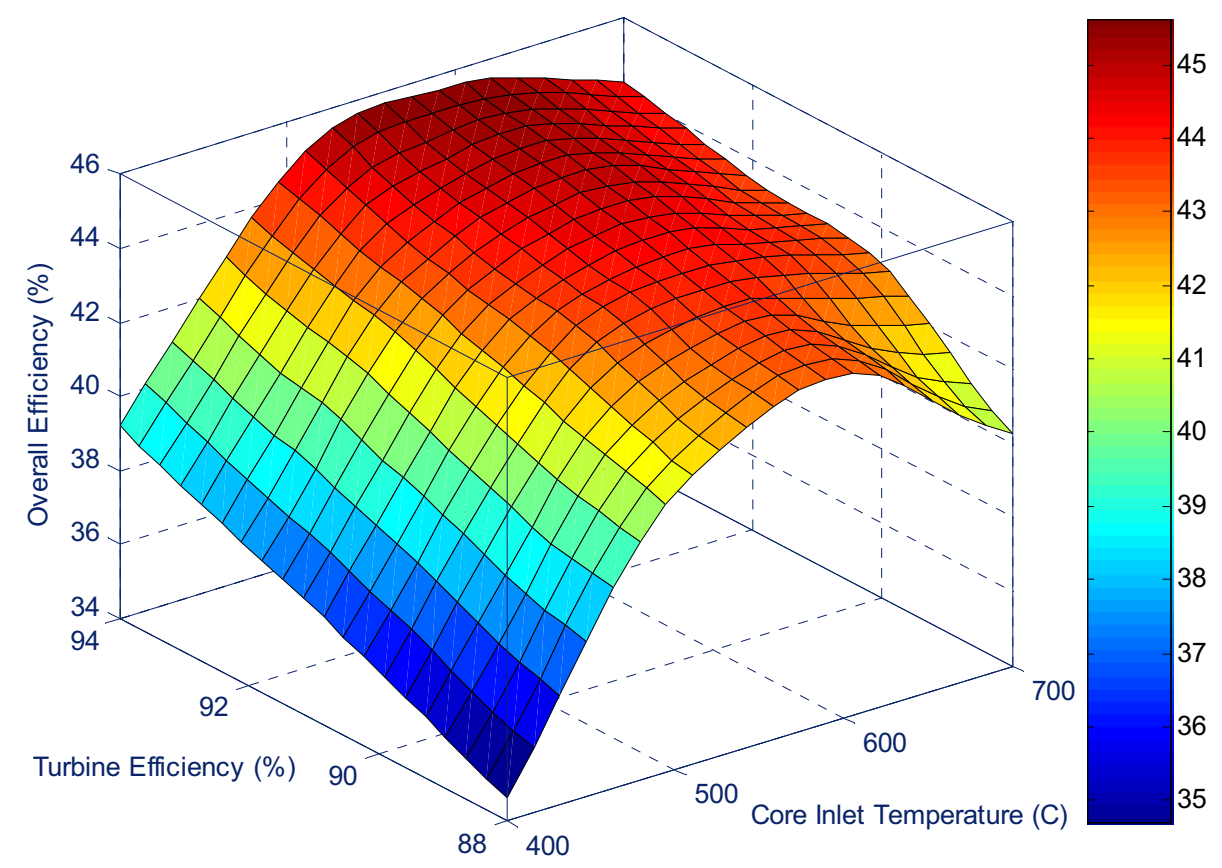

Figure 13. Effect of core inlet temperature and turbine efficiency on overall plant efficiency (He-He-He).

Figure 14 shows the effect of ternary loop (intermediate heat transport loop) flow rate on the overall efficiency. In this calculation, the overall efficiency is decreased as the flow rate is increased. It is because the lower flow rate requires less circulation power. However, the effect of ternary loop flow rate was nearly negligible around the optimal temperature, because the portion of ternary loop circulation power was too small compared with the other part. In this calculation, the effect of ternary loop flow rate seems very effective especially at a core inlet temperature below $500^{\circ} \mathrm{C}$, since the low core inlet temperature results in low PCU flow rate, and the flow rate in turbine cycle is relatively decreased with the ternary flow rate. Therefore, it leads to the overall efficiency drop. 


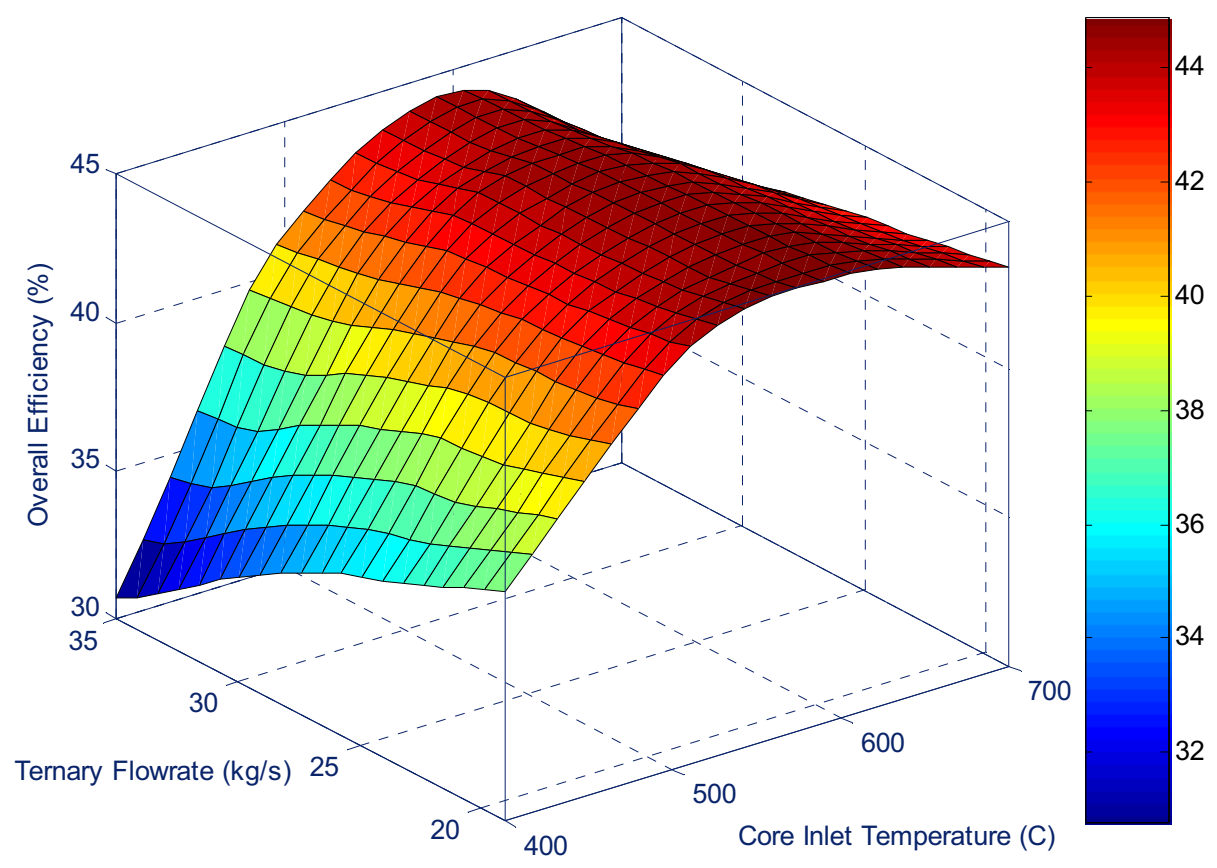

Figure 14. Effect of core inlet temperature and ternary flow rate on overall plant efficiency (He-He-He).

Figure 15 shows the effect of the medium pressure compressor (MPC) outlet pressure on the overall efficiency. The MPC outlet is the position where the highest system pressure is located. According to the figure, at low temperature, the efficiency is highly affected by the increase of the MPC outlet pressure, while it is only slightly affected around the optimal core inlet temperature. Figure 16 illustrates the variation of optimal pressure ratio along the MPC outlet pressure and the core inlet temperature. It shows the optimal pressure ratio increases significantly as the core inlet temperature decreases, while the variation by the MPC outlet pressure is very slight. It means the optimal pressure ratio is a sensitive factor to the PCU flow rate. Generally, PCU flow rate determines the PCU operating temperature range and it also determines the optimal operating pressure range. 


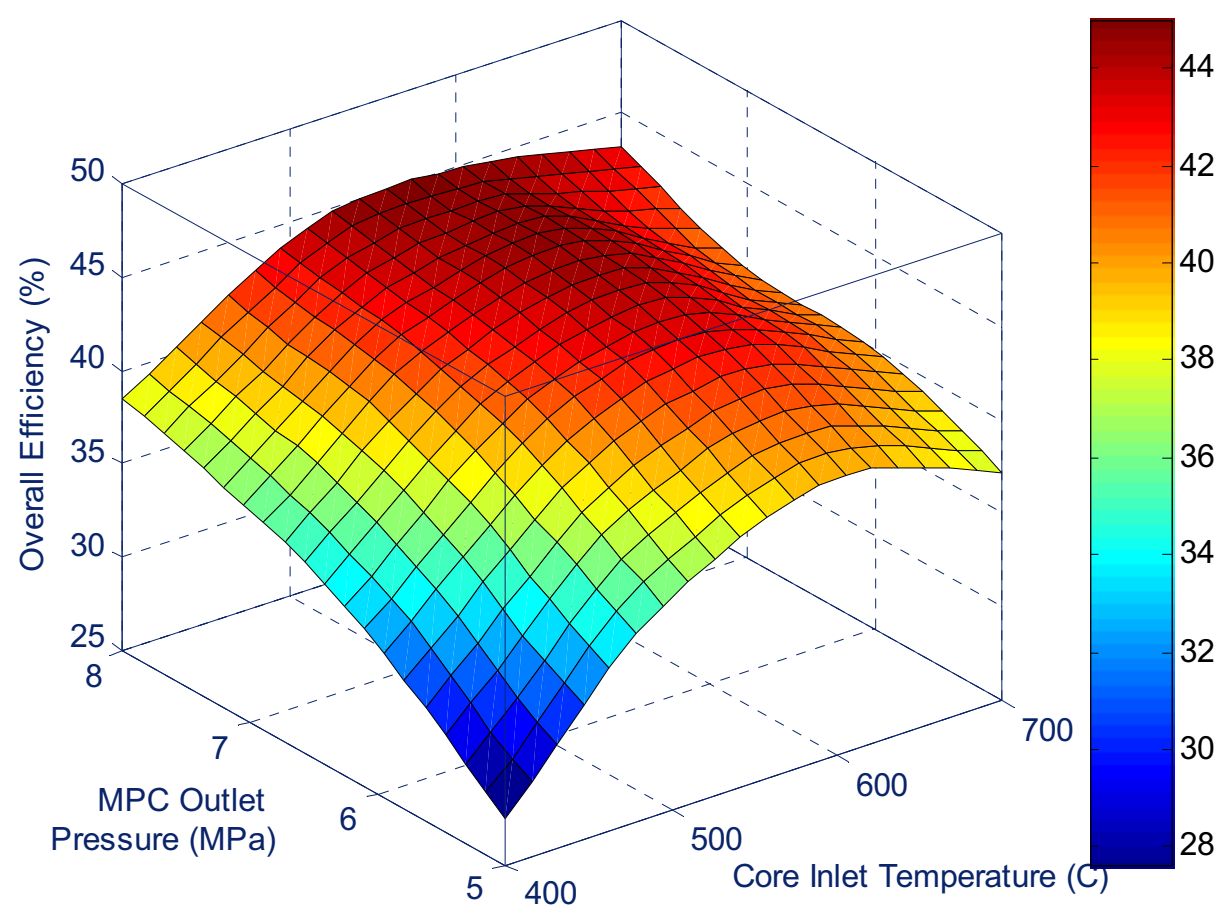

Figure 15. Effect of core inlet temperature and MPC outlet pressure on overall plant efficiency (He-He$\mathrm{He})$.

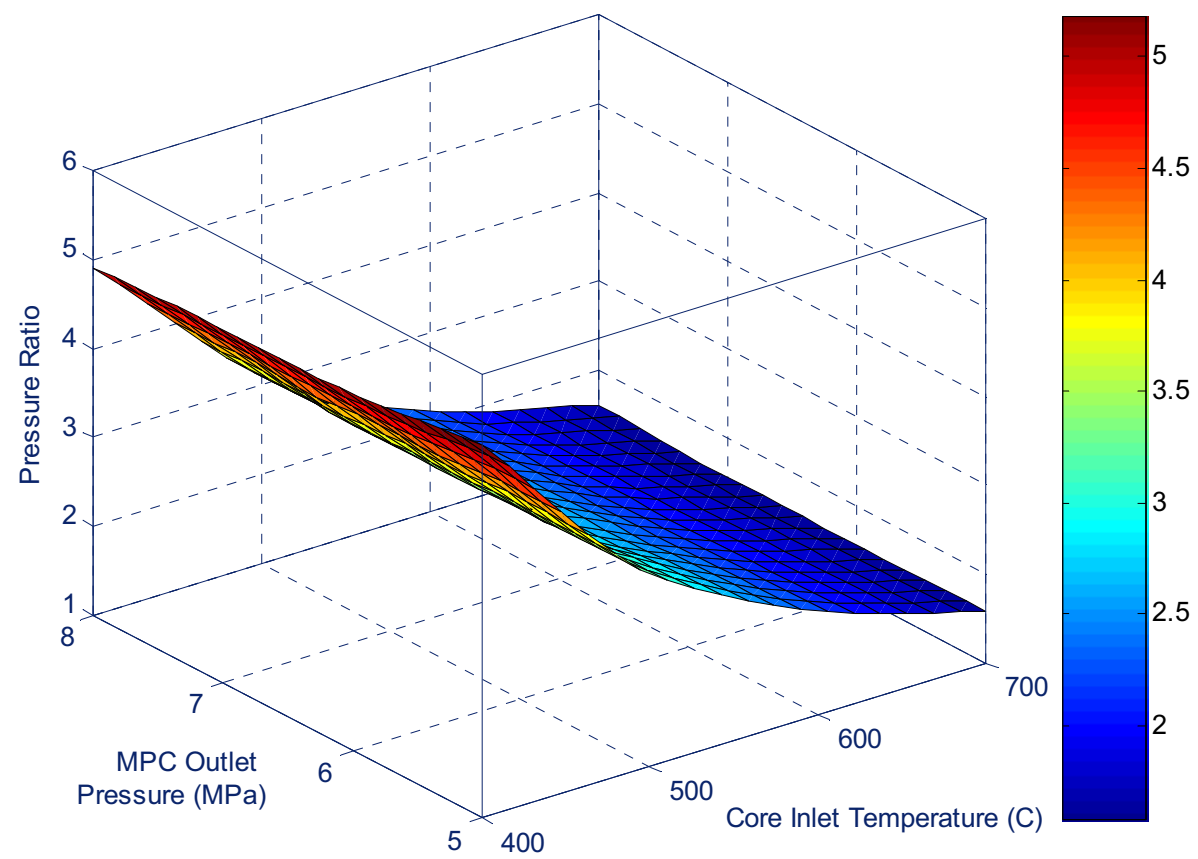

Figure 16. Effect of core inlet temperature and MPC outlet pressure on pressure ratio (He-He-He). 
Finally, the effect of heat exchanger effectiveness on the overall efficiency was estimated. As shown in Figure 17, the efficiency increases with the heat exchanger effectiveness. These trends are similar at both low and high core inlet temperatures. As a result, one percent increase of heat exchanger effectiveness increases the overall efficiency by around $0.5 \sim 0.8 \%$. It means effective heat exchanger performance is a very important factor for achieving more effective system performance. Since the increase of the effectiveness usually requires larger effective surface area, which increases the heat exchanger size and the capital cost, an optimal VHTR system requires a heat exchanger with a very high effectiveness. In this study, the printed circuit heat exchanger (PCHE) is considered as the main heat exchanger in the VHTR, with a commonly accepted effectiveness of around $95 \%$.

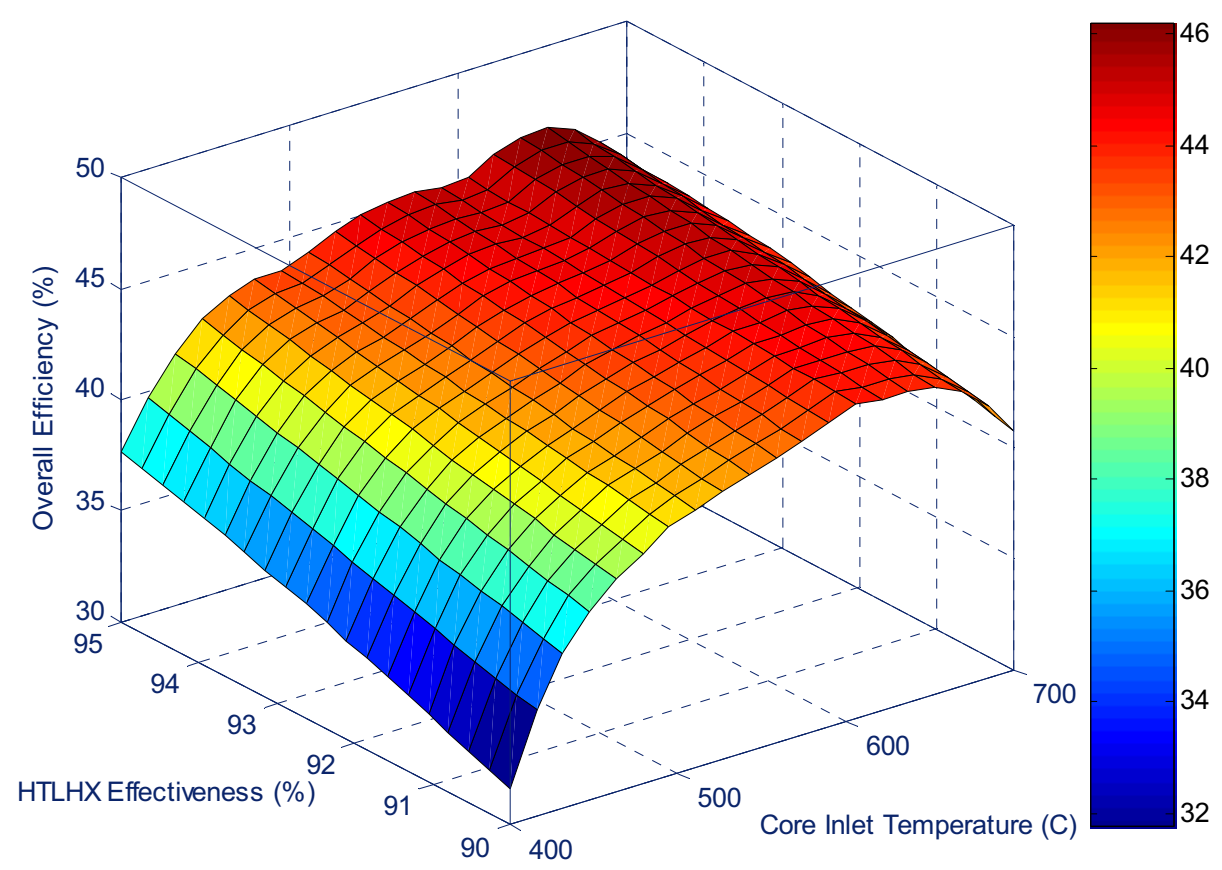

Figure 17. Effect of core inlet temperature and SHX effectiveness on overall plant efficiency (He-He-He).

\section{OPTIMIZATION RESULTS}

In the study, we estimated the system efficiencies for various system configurations and working fluids. The results are described below.

\subsection{Configuration 1 - Indirect Parallel Cycle}

Table 2 summarizes the calculated system efficiencies for Configuration 1. In this table, the primary flow loop includes the reactor core and the hot side of the IHX while the secondary loop includes the PCU and the ternary loop contains the intermediate heat transport loop that connects the SHX and the HTSE system. As a primary working fluid, Helium and Flinak were evaluated, as a secondary fluid, Helium and 
$\mathrm{S}-\mathrm{CO}_{2}$, and as a ternary fluid, Helium, $\mathrm{S}-\mathrm{CO}_{2}$, and Flinak were evaluated. A total of twelve different combinations of working fluids were evaluated.

In this calculation, Flinak in the primary loop increased the overall efficiency by $1.4 \%$ on average compared to Helium. Essentially, liquid phase (Flinak) requires less circulation power than the high pressure gas phase (Helium). The highest efficiency using helium in the primary flow loop was achieved in Case 3 (He-He-Flinak) while Case 9 (Flinak-He-Flinak) resulted in the maximum overall efficiency. With this configuration, the flow rate of Flinak, $1318 \mathrm{~kg} / \mathrm{s}$, is three times higher than the one of He, 478.4 $\mathrm{kg} / \mathrm{s}$, however, its circulation power is only 1/140 of He (Flinak: $104.7 \mathrm{~kW}$, He: $14770 \mathrm{~kW}$ ). This results in a slight efficiency increase with molten salt. Due to the higher density of the molten salt by a factor of 500 compared with that of Helium, we expect that Flinak system would require smaller core volume resulting in some economical advantages.

Table 2. Optimized efficiencies for Configuration 1

\begin{tabular}{|c|c|c|c|}
\hline Primary & Secondary & Ternary & Efficiency (\%) \\
\hline $\mathrm{He}$ & $\mathrm{He}$ & $\mathrm{He}$ & 44.12 \\
\hline $\mathrm{He}$ & $\mathrm{He}$ & $\mathrm{CO}_{2}$ & 44.47 \\
\hline $\mathrm{He}$ & $\mathrm{He}$ & Flinak & 46.13 \\
\hline $\mathrm{He}$ & $\mathrm{CO}_{2}$ & $\mathrm{He}$ & 43.35 \\
\hline $\mathrm{He}$ & $\mathrm{CO}_{2}$ & $\mathrm{CO}_{2}$ & 43.5 \\
\hline $\mathrm{He}$ & $\mathrm{CO}$ & $\mathrm{Flinak}$ & 43.41 \\
\hline Flinak & $\mathrm{He}$ & $\mathrm{He}$ & 45.25 \\
\hline Flinak & $\mathrm{He}$ & $\mathrm{CO}_{2}$ & 45.5 \\
\hline Flinak & $\mathrm{He}$ & Flinak & 47.24 \\
\hline Flinak & $\mathrm{CO}_{2}$ & $\mathrm{He}$ & 44.83 \\
\hline Flinak & $\mathrm{CO}_{2}$ & $\mathrm{CO}_{2}$ & 45.06 \\
\hline Flinak & $\mathrm{CO}_{2}$ & Flinak & 45.39 \\
\hline
\end{tabular}

In the ternary loop, Flinak shows the highest performance due to the reduced pumping power compared with gas and as a result, approximately $0.5 \%$ of efficiency improvement was achieved on average. The reason why the improvement in the ternary loop is smaller than in the primary loop is that the circulation power of the ternary loop is much less than the primary loop.

From the above results, we could conclude that Flinak-He-Flinak system is the most effective working fluids in the primary, secondary and the ternary flow loop in terms of the overall system efficiency. The efficiency of this combination is $47.24 \%$, the greatest of all combinations evaluated. Figures 18 and 19 illustrate the operating conditions for the optimized VHTR (Flinak-He-Flinak) and HTSE system, respectively. Figures 20 and 21 illustrate the P-V and T-S diagrams for the PCU in this system (FlinakHe-Flinak). These results will be benchmarked later with the HyPEP code. 


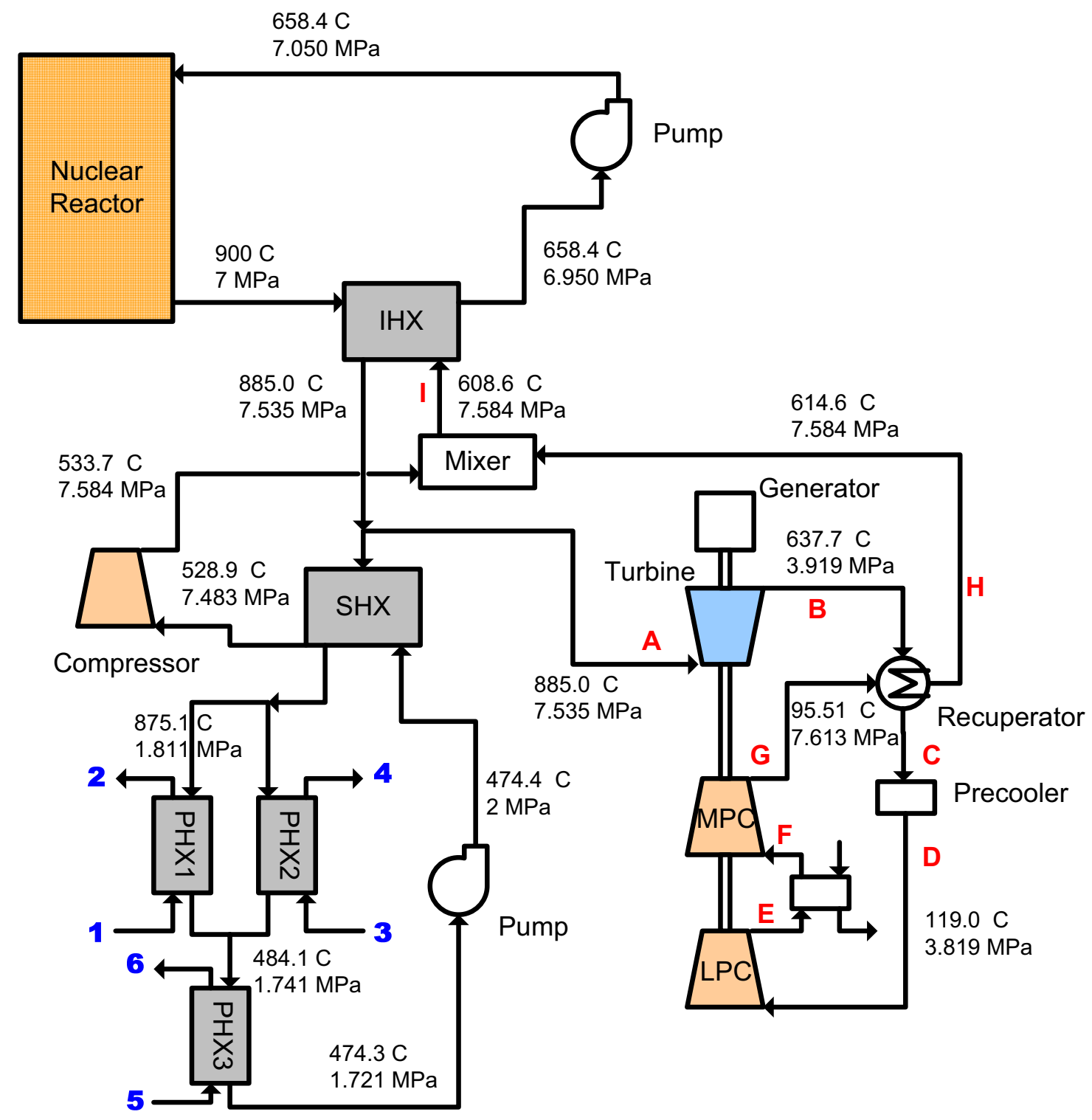

Figure 18. Plant operating conditions for Configuration 1 (Flinak - He - Flinak). 


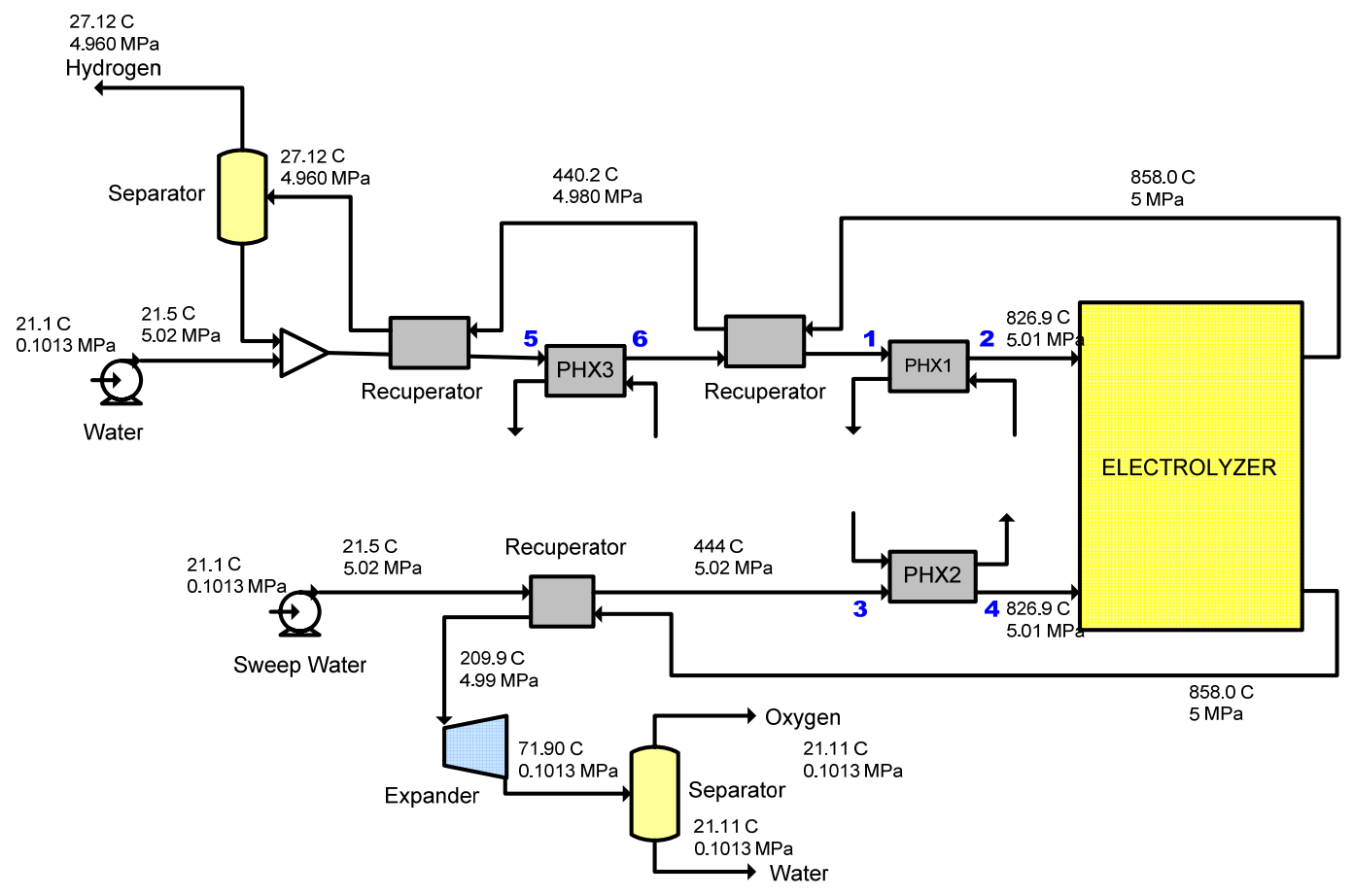

Figure 19. Operating conditions for the HTSE system.

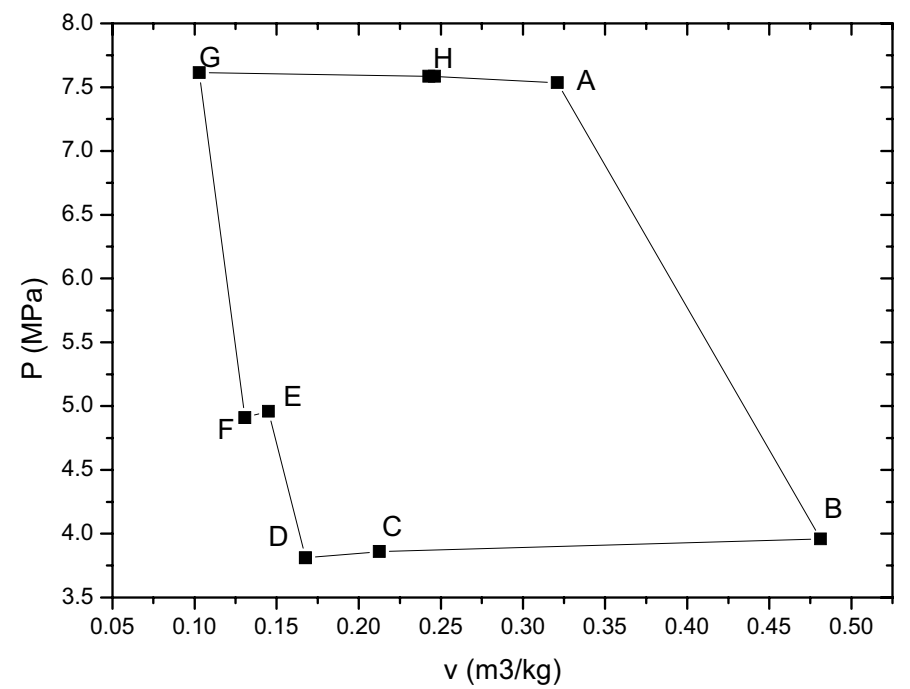

Figure 20. P-V diagram for Configuration 1 (Flinak-He-Flinak). 


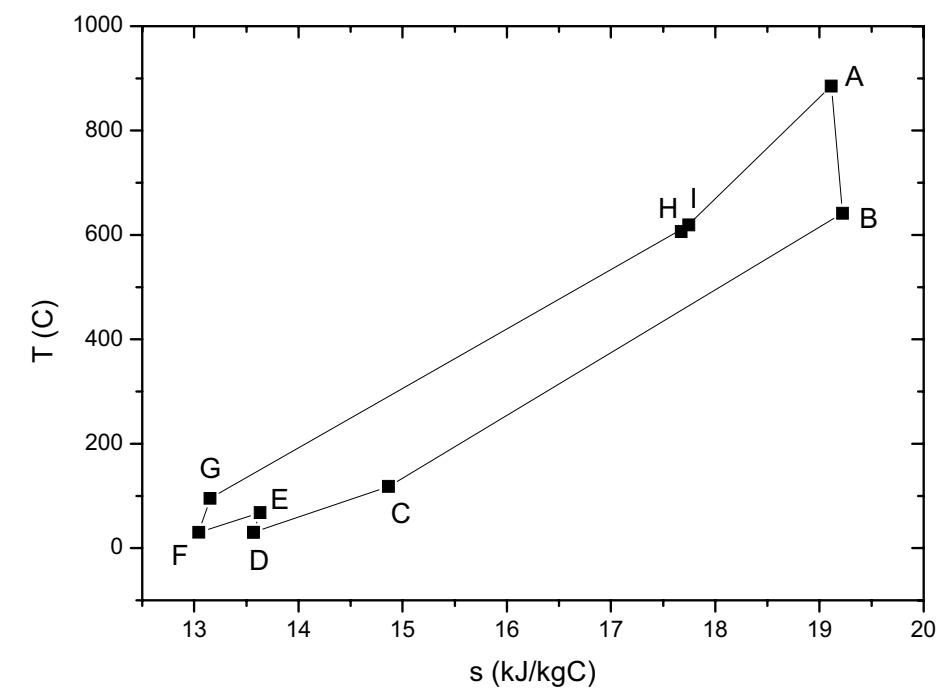

Figure 21. T-S diagram for Configuration 1 (Flinak-He-Flinak).

\subsection{Configuration 2 - Indirect Serial Cycle}

The optimized results for the indirect serial cycle are summarized in Table 3. Like Configuration 1, the primary, secondary and ternary loops contain the reactor, the PCU, and the intermediate heat transport loop, respectively.

Table 3. Optimized efficiencies for Configuration 2.

\begin{tabular}{|c|c|c|c|}
\hline Primary & Secondary & Ternary & Efficiency (\%) \\
\hline $\mathrm{He}$ & $\mathrm{He}$ & $\mathrm{He}$ & 46.26 \\
\hline $\mathrm{He}$ & $\mathrm{He}$ & $\mathrm{CO}_{2}$ & 46.32 \\
\hline $\mathrm{He}$ & $\mathrm{He}$ & $\mathrm{Flinak}$ & 46.32 \\
\hline $\mathrm{Ce}$ & $\mathrm{CO}$ & 45.02 \\
\hline $\mathrm{He}$ & $\mathrm{CO}_{2}$ & $\mathrm{CO}_{2}$ & 45.09 \\
\hline $\mathrm{He}$ & $\mathrm{CO}_{2}$ & $\mathrm{Flinak}$ & 45.09 \\
\hline Flinak & $\mathrm{He}$ & $\mathrm{He}$ & 48.13 \\
\hline Flinak & $\mathrm{He}$ & $\mathrm{CO}_{2}$ & 48.3 \\
\hline Flinak & $\mathrm{He}$ & $\mathrm{Flinak}$ & 48.38 \\
\hline Flinak & $\mathrm{CO}_{2}$ & $\mathrm{He}$ & 46.9 \\
\hline Flinak & $\mathrm{CO}_{2}$ & $\mathrm{CO}_{2}$ & 47.07 \\
\hline Flinak & $\mathrm{CO}_{2}$ & Flinak & 47.15 \\
\hline
\end{tabular}

The maximum efficiency (48.38 \%) was obtained for Flinak-He-Flinak combination. It is due to the reduction of circulation power for the primary and the ternary side caused by liquid coolant. As a result, The overall efficiency for Configuration 2 is about $1 \%$ higher than for Configuration 1, even though the turbine inlet temperature is a little reduced. The increase in efficiency is due to the decreased number of circulators. The elimination of one circulator and flow splitter is also expected to result in lower capital cost and higher controllability. 
Figure 22 shows the optimized operating conditions for Configuration 2. Since the working fluid of the primary and the ternary loop is Flinak, the circulator in the original configuration (Figure 8) is changed to a pump. In the ternary loop, the minimum temperature is maintained above $454^{\circ} \mathrm{C}$, the melting temperature of Flinak.

The core outlet temperature is maintained at $900{ }^{\circ} \mathrm{C}$, and the optimal core inlet temperature is calculated to be $673.6{ }^{\circ} \mathrm{C}$ by the energy balance around the VHTR. The effectiveness of the IHX and SHX was used as 0.95 . The turbine inlet temperature $\left(870{ }^{\circ} \mathrm{C}\right)$ is little reduced compared with the Configuration 1 $\left(885^{\circ} \mathrm{C}\right)$. At the optimal condition, the pressure ratio is 1.89 . The operating conditions of the HTSE system are the same as for Configuration 1. Figures 23 and 24 illustrate the P-V and T-S diagrams for the optimized conditions (Flinak-He-Flinak).

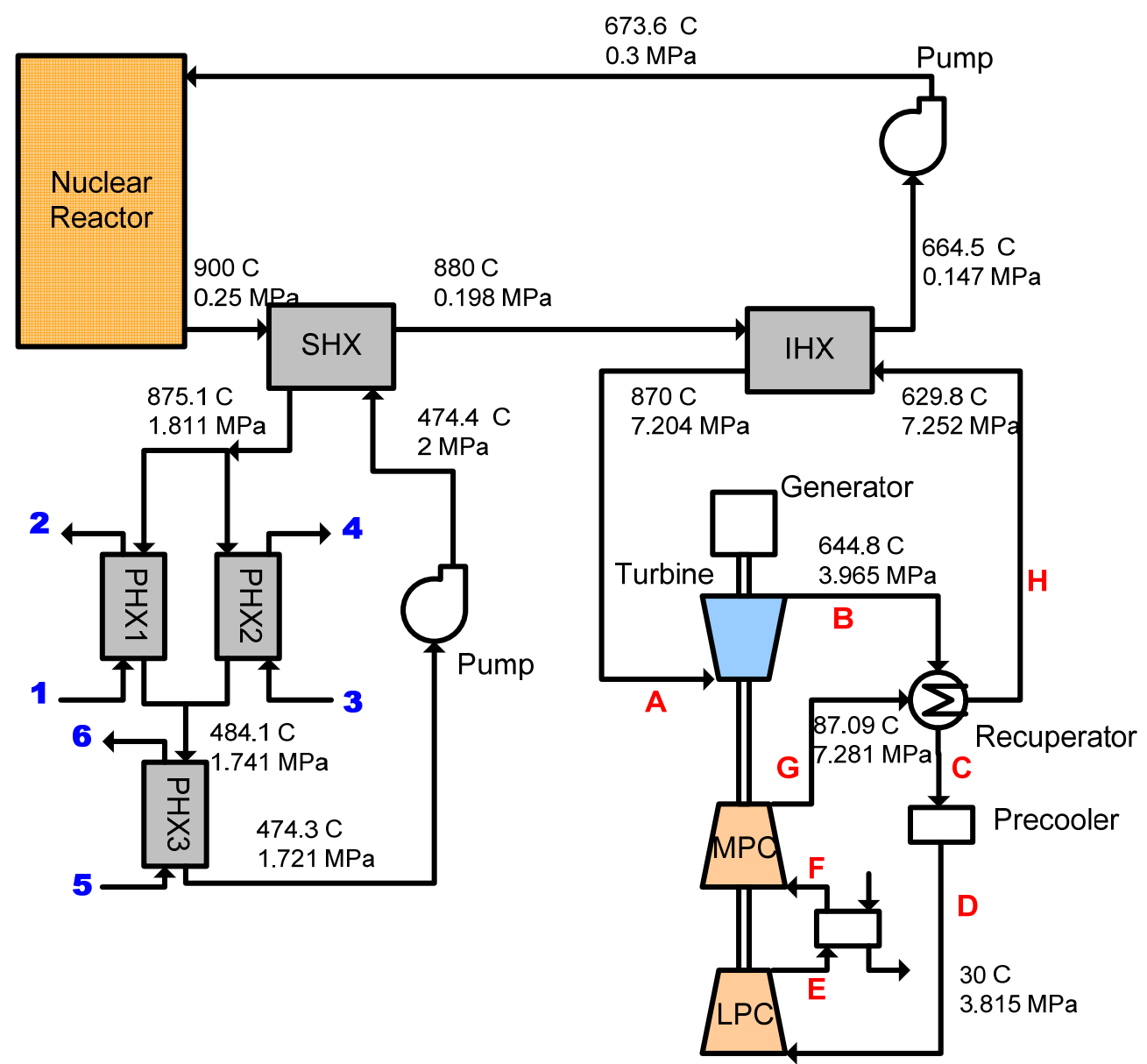

Figure 22. Optimized operating conditions for Configuration 2 (Flinak $-\mathrm{He}-$ Flinak) 


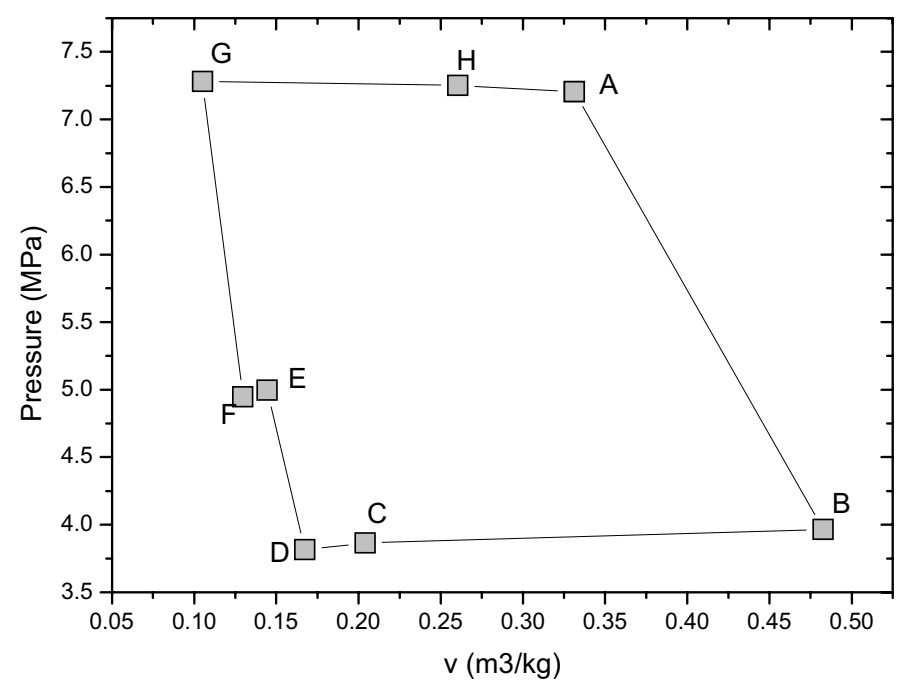

Figure 23. P-V diagram for Configuration 2 (Flinak-He-Flinak).

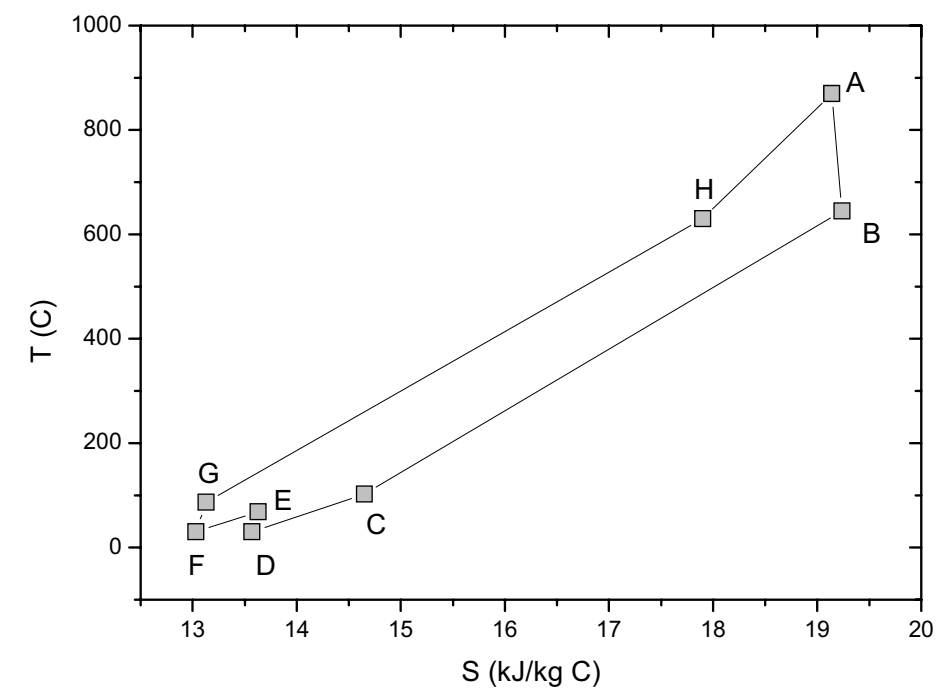

Figure 24. T-S diagram for Configuration 2 (Flinak-He-Flinak).

\subsection{Configuration 3 - Direct Serial Cycle}

Table 4 summarizes the estimated efficiencies for Configuration 3 . This configuration is a direct cycle, so the PCU is in series with the reactor in the primary system. The reactor and PCU both use the same working fluid, which precludes the use of the molten salt as a coolant. At high temperatures, $\mathrm{CO}_{2}$ will react with the graphite materials in the VHTR core. As a consequence the inert gas helium is used in this 
application to avoid chemical oxidation in the core. In the ternary loop (intermediate heat transport loop), three working fluids were evaluated: $\mathrm{He}, \mathrm{CO}_{2}$, and Flinak.

As mentioned above, the direct cycle has many benefits for efficiencies and cost effectiveness by eliminating the IHX and primary circulator. In our calculation, the maximum efficiency of Configuration 3 was found to be $48.96 \%$. Comparing this with Configuration 2, the maximum efficiency increase of Configuration 3 was only $0.5 \%$. This is attributed to the already low pumping power in the primary side of Configuration 2 as a consequence of Flinak coolant $(185 \mathrm{~kW})$.

Table 4. Optimized efficiencies for Configuration 3.

\begin{tabular}{|c|c|c|c|}
\hline Primary & Secondary & Ternary & Efficiency (\%) \\
\hline $\mathrm{He}$ & $\mathrm{He}$ & $\mathrm{He}$ & 48.48 \\
\hline $\mathrm{He}$ & $\mathrm{He}$ & $\mathrm{CO}_{2}$ & 48.77 \\
\hline $\mathrm{He}$ & $\mathrm{He}$ & Flinak & 48.96 \\
\hline
\end{tabular}

Figure 25 illustrates the optimized operating conditions for Configuration 3 . The core outlet temperature is maintained at $900{ }^{\circ} \mathrm{C}$, and the optimal core inlet temperature is calculated to be $622.0^{\circ} \mathrm{C}$. The SHX effectiveness was 0.95 . The turbine inlet temperature $\left(873.5^{\circ} \mathrm{C}\right)$ is reduced compared with the Configuration $1\left(885^{\circ} \mathrm{C}\right)$, but it is little higher than the Configuration 2 . At the optimal condition, the pressure ratio is 1.97 . The operating conditions of the HTSE system are the same as the Configuration 1. Figures 26 and 27 illustrate the P-V and T-S diagram for the optimized conditions (He-He-Flinak).

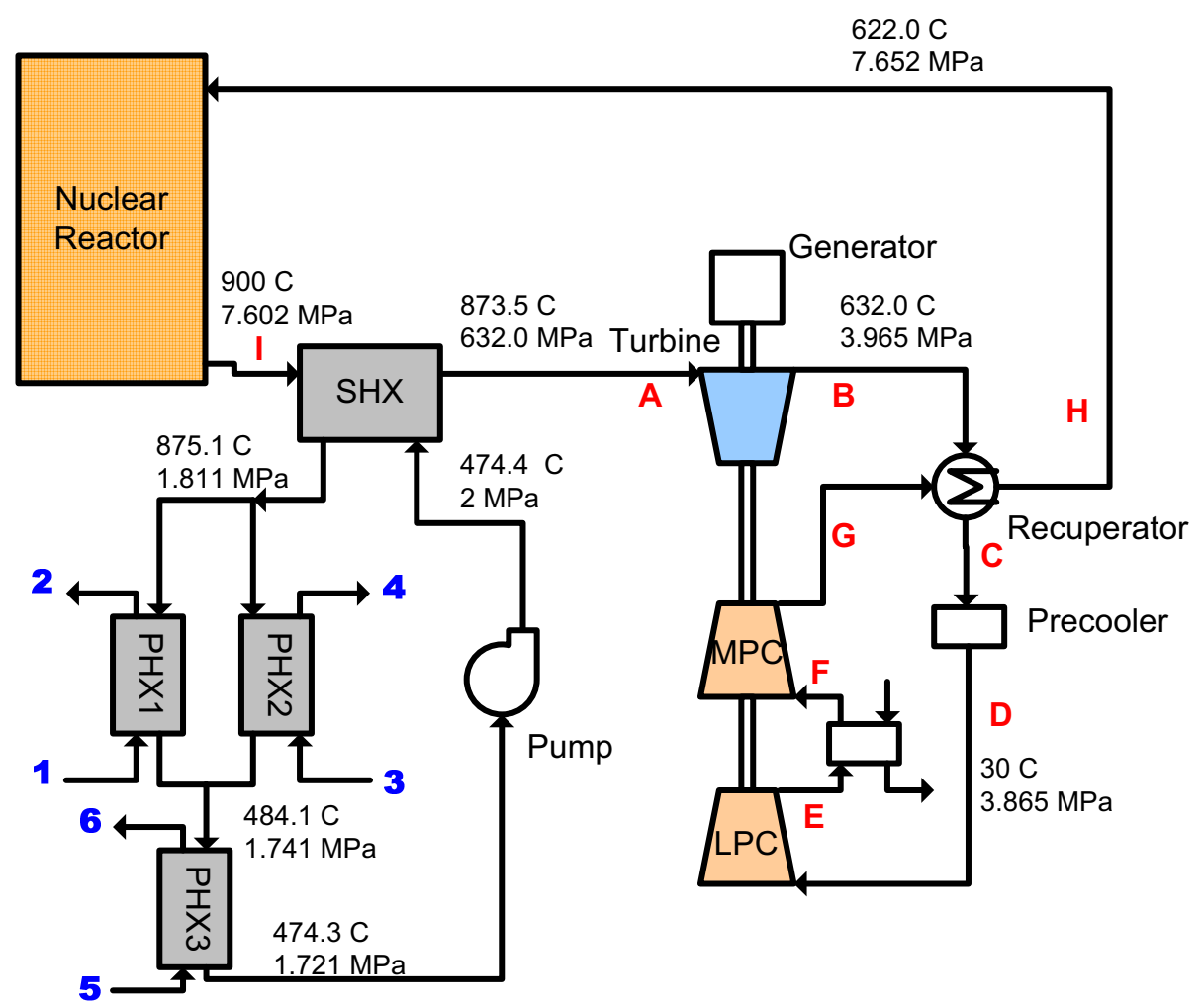

Figure 25. Optimized operating conditions for Configuration 3 (He-He-Flinak). 


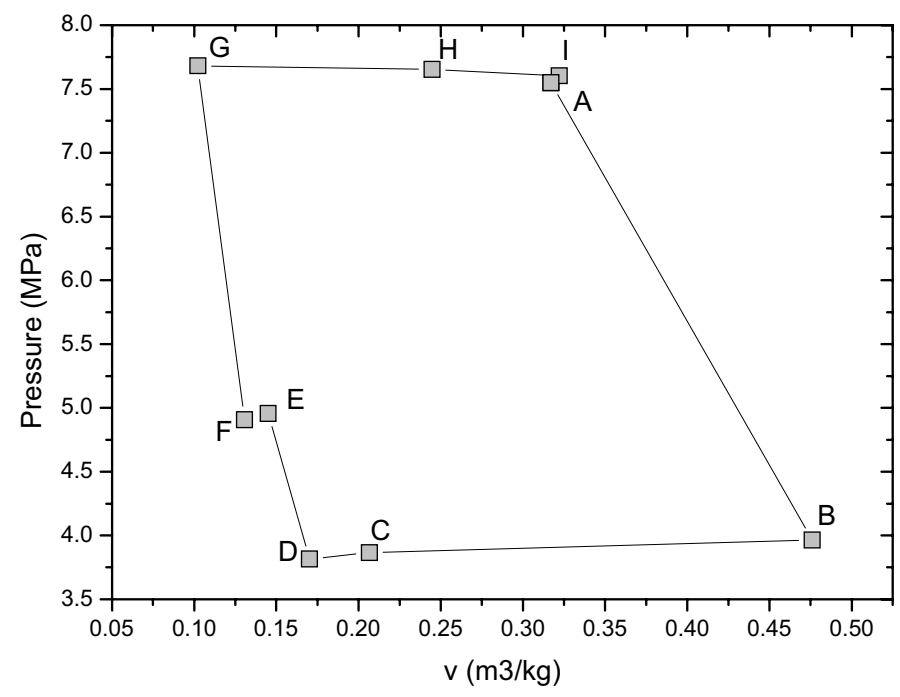

Figure 26. P-V diagram for Configuration 3 (He-He-Flinak).

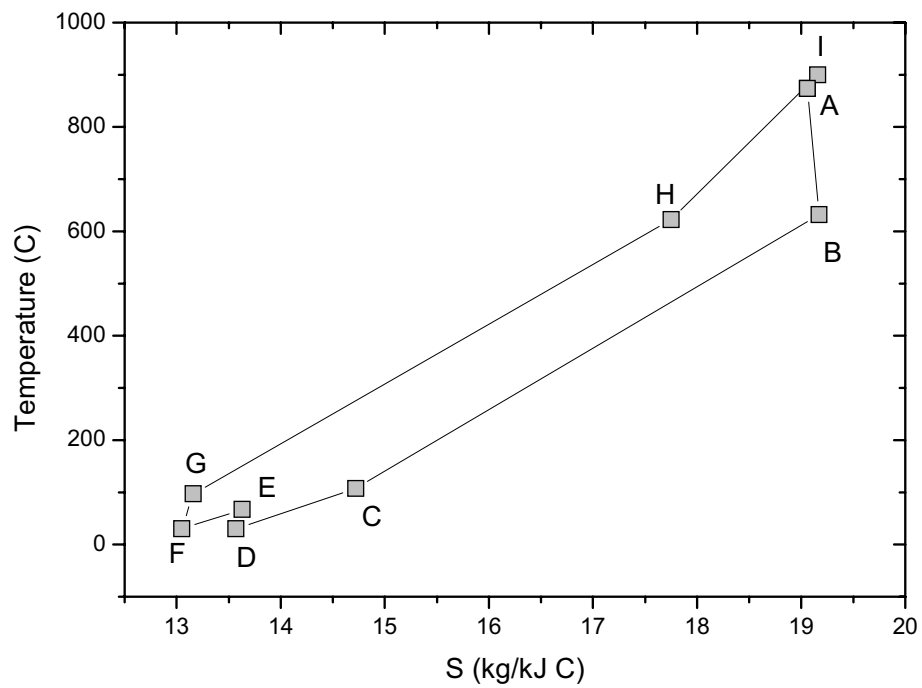

Figure 27. T-S diagram for Configuration 3 (He-He-Flinak).

\subsection{Configuration 4 - Steam Combined Cycle}

Configuration 4 is a steam combined cycle. In this system, a steam turbine system is utilized to recover the heat discharged from the turbine outlet instead of the recuperator. Usually, this kind of configuration gives higher efficiency than that of normal recuperation cycle. Table 5 summarizes the optimized efficiencies for Configuration 4. In our calculation, the maximum efficiency of $44.32 \%$ was obtained for Flinak- $\mathrm{CO}_{2}$-Flinak combination. This is significantly lower efficiency than those of the other configurations using Flinak. It means that the recuperation is more effective way to recover the heat at the 
turbine outlet, because the temperature difference between the outlet of the turbine and the compressor is high. Essentially, the difference between average temperature of heat addition and average temperature of heat rejection is greater in the case of the recuperated gas reactor. As a consequence the Carnot efficiency is greater.

Figure 28 illustrates the optimized condition (Flinak- $\mathrm{CO}_{2}$-Flinak). In this system, the heat generated in the core is transferred to the PCU loop through the IHX. The heated flow in the PCU is split into two streams, one for electricity generation by the turbine cycle and the other for transferring energy to the HTSE through the SHX. Configuration 4 is basically the same as the indirect parallel cycle (Configuration 1), but it has only one compressor. We think it is one of the main reasons of the resultant low efficiency of this configuration is due to a higher inlet temperature to the compressor with no intercooler.

The core outlet temperature is maintained at $900{ }^{\circ} \mathrm{C}$, and the optimal core inlet temperature is obtained as $548.8^{\circ} \mathrm{C}$. The IHX and SHX effectiveness were 0.95. At the optimal condition, the pressure ratio is 8.76. The operating conditions of the HTSE system are the same as Configuration 1. Figures 29 and 30 illustrate the P-V and T-S diagram for the optimized conditions (Flinak- $\mathrm{CO}_{2}$-Flinak).

Table 5. Optimized efficiencies for Configuration 4 (Steam combined cycle)

\begin{tabular}{|c|c|c|c|}
\hline Primary & Secondary & Ternary & Efficiency (\%) \\
\hline $\mathrm{He}$ & $\mathrm{He}$ & $\mathrm{He}$ & 42.09 \\
\hline $\mathrm{He}$ & $\mathrm{He}$ & $\mathrm{CO}_{2}$ & 42.45 \\
\hline $\mathrm{He}$ & $\mathrm{He}$ & $\mathrm{Flinak}$ & 42.77 \\
\hline $\mathrm{He}$ & $\mathrm{CO}_{2}$ & $\mathrm{He}$ & 43.46 \\
\hline $\mathrm{Ce}$ & $\mathrm{CO}_{2}$ & $\mathrm{CO}_{2}$ & 44.06 \\
\hline $\mathrm{He}$ & $\mathrm{CO}$ & Flinak & 44.3 \\
\hline Flinak & $\mathrm{He}$ & $\mathrm{He}$ & 42.79 \\
\hline Flinak & $\mathrm{He}$ & $\mathrm{CO}_{2}$ & 42.98 \\
\hline Flinak & $\mathrm{He}$ & Flinak & 43.29 \\
\hline Flinak & $\mathrm{CO}_{2}$ & $\mathrm{He}$ & 44.32 \\
\hline Flinak & $\mathrm{CO}_{2}$ & $\mathrm{CO}_{2}$ & 44.55 \\
\hline Flinak & $\mathrm{CO}_{2}$ & Flinak & 44.88 \\
\hline
\end{tabular}




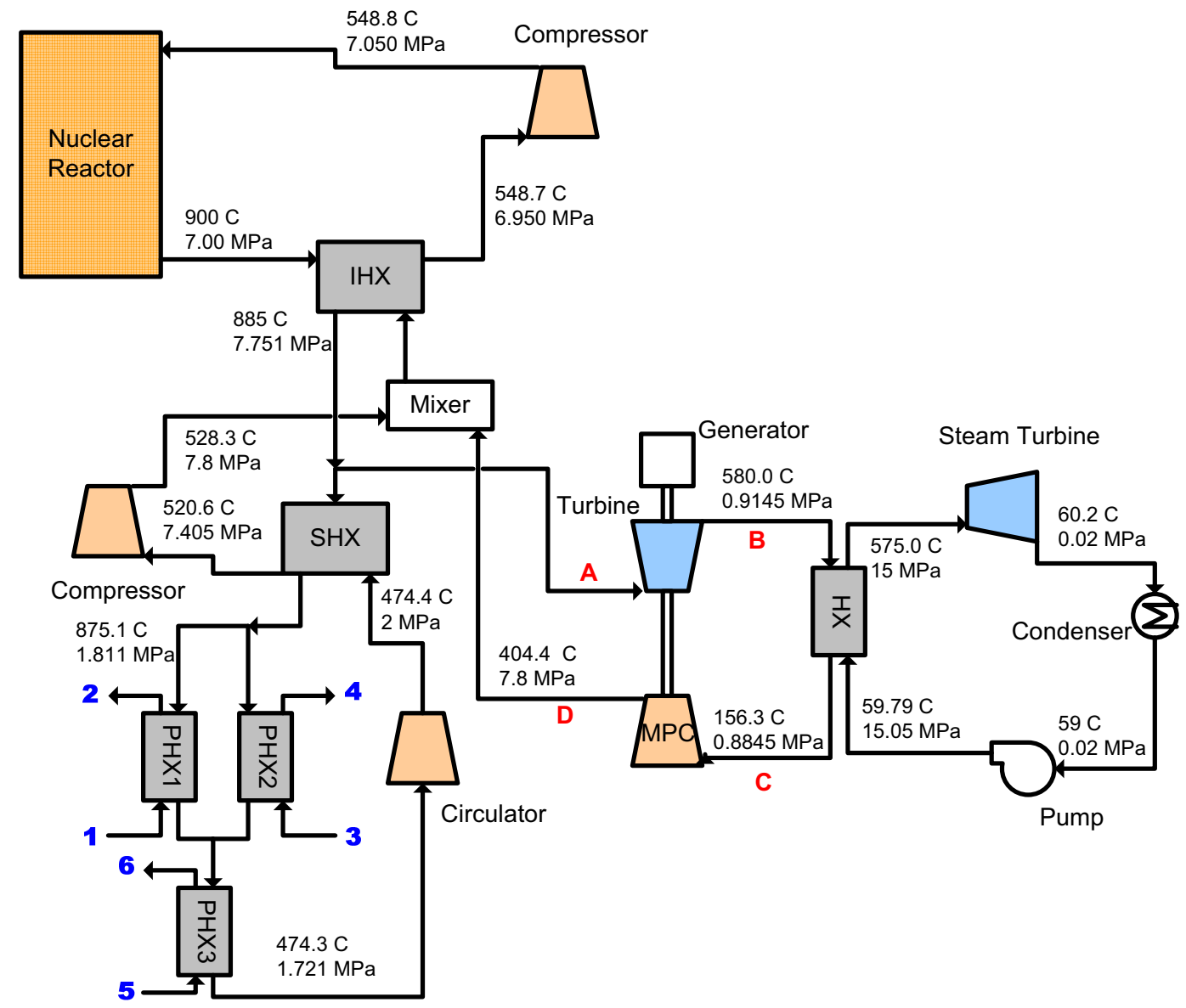

Figure 28. Optimized condition for Configuration 4 (Flinak- $\mathrm{CO}_{2}$-Flinak).

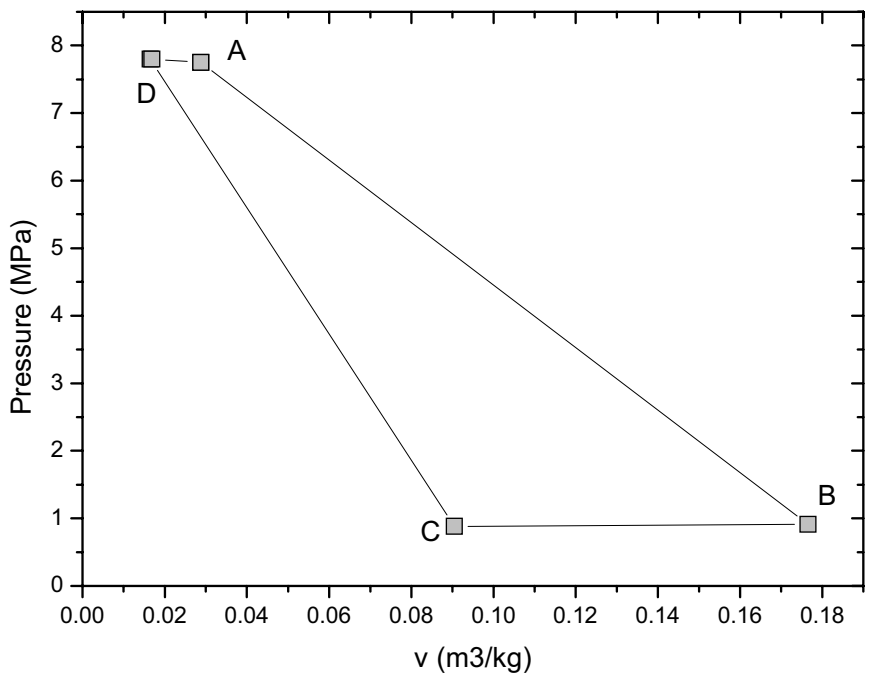

Figure 29. P-V diagram for Configuration 4 (Flinak- $\mathrm{CO}_{2}$-Flinak). 


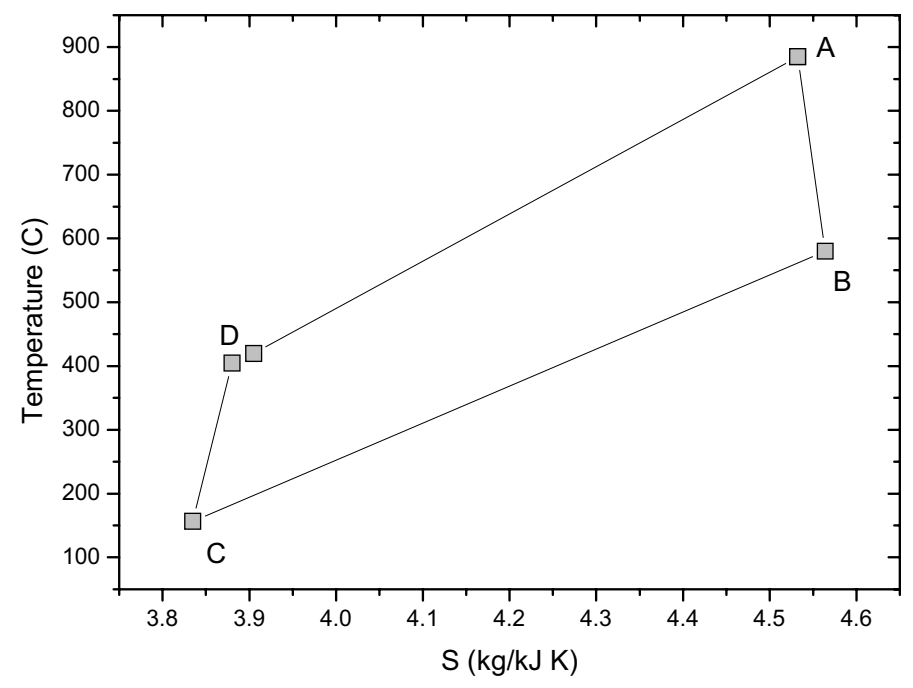

Figure 30. T-S diagram for Configuration 4 (Flinak- $\mathrm{CO}_{2}$-Flinak).

\subsection{Configuration 5 - Reheat Cycle}

Configuration 5 is a reheat cycle. In this system, the stream discharged from a turbine is reheated by the primary side and regenerates the electricity through another turbine. In this configuration, four turbines and four compressors were used. Table 6 summarizes the calculated efficiencies for various combinations of working fluids. The maximum efficiency obtained was $50.64 \%$ for the Flinak- $\mathrm{CO}_{2}-$ Flinak combination. Figure 31 shows the optimal condition for this system. The detailed conditions of each stream are shown in Figures 32 and 33, which are P-V and T-S diagrams, respectively.

The core outlet temperature is maintained at $900^{\circ} \mathrm{C}$, and the optimal core inlet temperature is obtained as $793^{\circ} \mathrm{C}$. The IHX and SHX effectiveness were 0.95. At the optimal condition, the pressure ratio is 9.314 . The operating conditions of the HTSE system are the same as the Configuration 1.

Although the efficiency of this system is much higher than the other configurations, it requires extra components (heat exchangers, turbines and compressors) increasing capital cost. In addition, the greater system complexity may give rise to control problems or perhaps safety issues. The optimal efficiency of this system was obtained at full power conditions. One would also need to investigate how efficiency behaves at reduced power and during transient operation. 
Table 6. Optimized efficiencies for Configuration 5.

\begin{tabular}{|c|c|c|c|}
\hline \multicolumn{1}{|c|}{ Primary } & Secondary & Ternary & Efficiency (\%) \\
\hline $\mathrm{He}$ & $\mathrm{He}$ & $\mathrm{He}$ & 47.04 \\
\hline $\mathrm{He}$ & $\mathrm{He}$ & $\mathrm{CO}_{2}$ & 47.2 \\
\hline $\mathrm{He}$ & $\mathrm{CO}_{2}$ & $\mathrm{Flinak}$ & 47.43 \\
\hline $\mathrm{He}$ & $\mathrm{He}$ & 47.4 \\
\hline $\mathrm{Ce}$ & $\mathrm{CO}_{2}$ & $\mathrm{CO}_{2}$ & 47.49 \\
\hline $\mathrm{He}$ & $\mathrm{He}$ & $\mathrm{Flinak}$ & 49.52 \\
\hline Flinak & $\mathrm{He}$ & 49.23 \\
\hline Flinak & $\mathrm{He}$ & $\mathrm{CO}_{2}$ & 49.4 \\
\hline Flinak & $\mathrm{CO}_{2}$ & $\mathrm{Flinak}$ & 49.76 \\
\hline Flinak & $\mathrm{CO}_{2}$ & $\mathrm{CO}_{2}$ & 49.6 \\
\hline Flinak & $\mathrm{CO}_{2}$ & Flinak & 49.77 \\
\hline Flinak & & \multicolumn{2}{c}{} \\
\hline
\end{tabular}
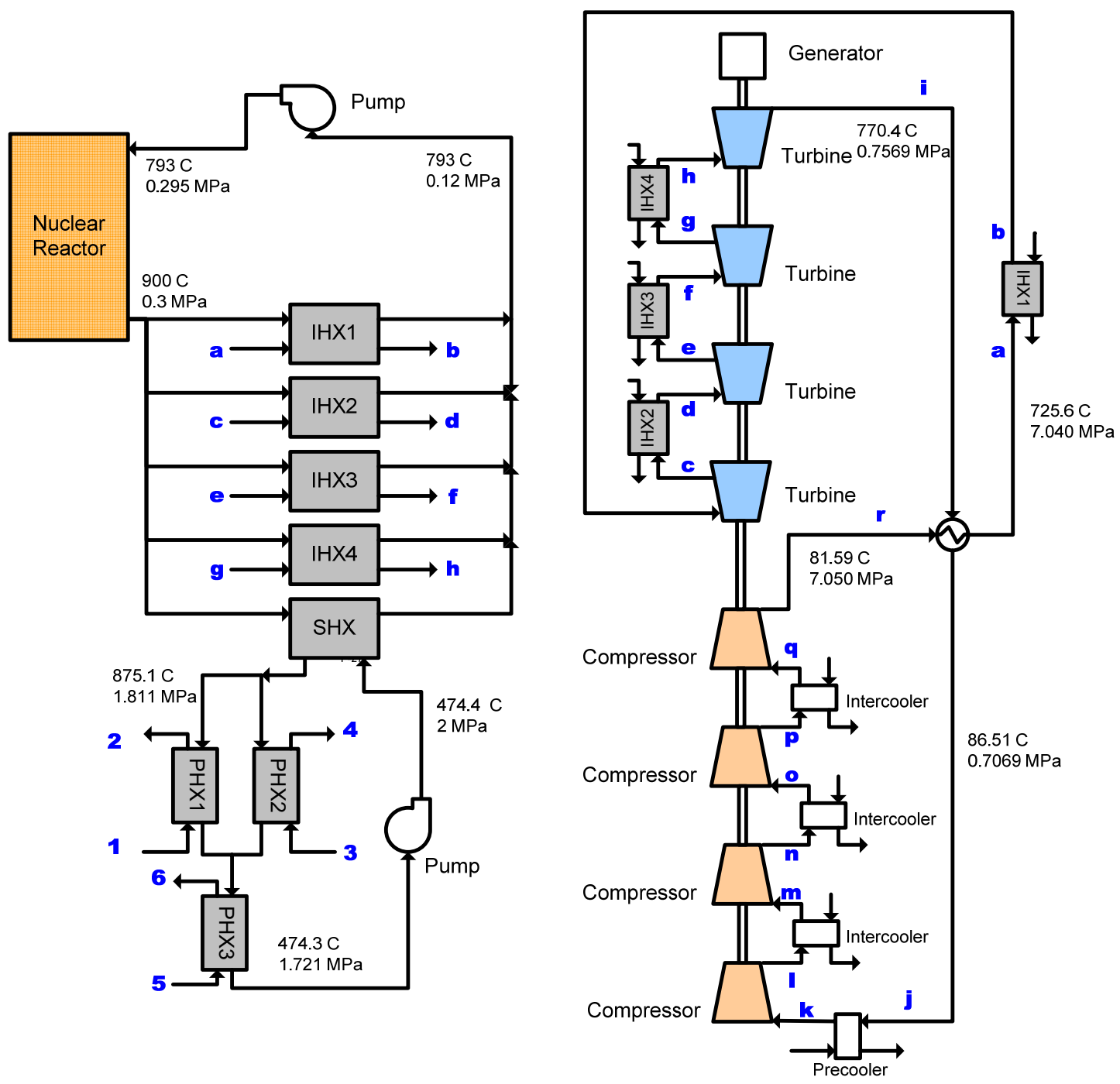

Figure 31. Optimized condition for Configuration 5 (Flinak- $\mathrm{CO}_{2}$-Flinak). 